\title{
ROMSKA NASELJA KOT POSEBEN DEL NASELBINSKEGA SISTEMA V SLOVENIJI
}

\author{
Jernej Zupančič \\ Oddelek za geografijo Filozofske fakultete Univerze v Ljubljani, Aškerčeva cesta 2, \\ SI - 1000 Ljubljana, Slovenija \\ e-mail: jernej.zupancic@guest.arnes.si \\ Izvirni znanstveni članek
}

COBISS 1.01

\section{Izvleček}

Prispevek obravnava romska naselja kot poseben del naselbinskega sistema v Sloveniji. Zaradi pozne stalne naselitve, ohranjanja svojskih bivalnih navad in pomanjkanja sredstev so Romi oblikovali več kot sto naselbinskih enot, ki so le deloma vključene v naselbinski sistem Slovenije. Zaradi tega imajo sami vrsto težav. Številni problemi nastajajo v stiku Romov in okoliškega prebivalstva. Vendar to stanje ni brezperspektivno; ob angažiranju lokalnih in državnih dejavnikov ter Romov samih je mogoče pričakovati izboljšanje njihovega položaja ter obenem razbremeniti okoliško prebivalstvo.

Ključne besede: politična geografija, manjšine, Romi, Slovenija, naselja

\section{ROMA SETTLEMENTS AS A SPECIFIC PART OF SETTLEMENT SYSTEM IN SLOVENIA}

\begin{abstract}
The paper analyse the Roma-settlements as a specific phenomenon of slovene settlement system. Roma people changed their way of life from nomadism to stabile settlement very late (in aftewar period) and remain some specifics in living-standard and have poor opportunities for social integration. That's why they have a lot of social problems, as well as confrontations and conflicts with local neighbours. But the situation is not perspectiveless: helped by local and national factors, some of Roma people are able to advance their standard of living, what makes, by the same time, the relations with other local population better.
\end{abstract}

Key words: political geography, minorities, Roma, Slovenia, settlements 


\section{UVOD}

Slovenija je v svetu prepoznavna po visokem standardu varstva manjšin. Območja poselitve $\mathrm{z}$ italijanskim in madžarskim prebivalstvom dejansko uživa nekatere prednosti ozemelj z nadpovprečno gostoto različnih družbenih institucij. Prisotnost pripadnikov manjšin tako dejansko pomeni določeno prednost. Nasprotno pa se občine z romskim prebivalstvom večinoma počutijo hendikepirane. Kljub nekaterim primerom dobre prakse, posebej v Prekmurju je v ospredju kritičnih razprav o Romih beseda »problematika« precej pogostejša od »tematike«. Čeprav je država vložila v projekte in programe družbene integracije Romov in odpravljanje njihove konfliktnosti z okoliškim prebivalstvom veliko energije in sredstev, se zdi izkupiček teh prizadevanj dokaj boren. Predvsem pa je treba že na začetku povedati, da so »romski« problemi izrazito lokalizirani: nastopajo na ravni bližnjih stikov romskega in neromskega prebivalstva.

Slovenska geografija se je doslej le skromno lotevala tematike Romov. Kot skupino jih prepoznavamo predvsem v luči socialnih problemov in kot pomemben del marginalnih družbenih skupnosti. Sporadične raziskave so jih predvsem omenjale, niso pa se lotevale poglobljenih terenskih raziskav. Morda so tudi zaradi tega ostali koncepti prostorskega razvoja in urejanja naselbinskih enot $\mathrm{z}$ romskim prebivalstvom precej zapostavljeni. Toda burni dogodki zaradi konfrontacij in konfliktov v zadnjih letih na eni ter povečana skrb države za urejanja romske problematike na drugi strani postavljajo to tematiko v ospredje (Zupančič, 2004). A povsem brez izkušenj geografi vendarle nismo. Problemski pristopi in upoštevanje tudi izsledkov drugih ved in znanstvenih disciplin razgalja doslej skoraj manj poznano področje, ki pa je lahko spričo še številnih problemov lahko delovno polje ne le političnim geografom, temveč tudi drugim geografskim vejam, zlasti na področju prostorskega planiranja, regionalnega razvoja, poselitve in varstva okolja. Lastno raziskovalno delo na tem področju v zadnjih letih me je prepričalo, da se te sicer pregovorno nehvaležne tematike splača geografom lotiti prav zaradi našega širokega in kar najbolj kompleksnega pristopa. Reševanje romske problematike sicer zajema vrsto ukrepov na različnih področjih: socialnem, ekonomskem, pravnem, političnem, izobraževalnem, kulturnem in prostorskem. Urejanje bivalnih pogojev romskega prebivalstva je sicer vseskozi zaznaven problem, ki pa doslej ni bil v ospredju proučevanja Romov, niti reševanja njihovih specifičnih problemov na lokalnih ravneh. Dosedanja obsežnejša dela o romski tematiki so prostorski vidik le omenjala, najpogosteje ob socialnem in zaposlitvenem vprašanju (Klien, 1999, 107) ter pri težavnem in pogosto neuspešnem prehajanju iz družbeno marginalne skupnosti v družbeno povprečje (Tichy, 1999; Žagar, 1999, 81-84). V resnici je prostorski vidik romskega vprašanja postal problematičen kmalu po začetkih prostorske stabilizacije in prenehanju nomadskega načina življenja Romov (Štrukelj, 1991). V preteklih desetletjih je so se prostorska vprašanja večinoma obravnavala v kontekstu bivalnih razmer; očitno je bilo torej zaznavanja problema prisotno že dalj časa, njegovo reševanje pa omejeno na segmente bivanja in stanovanja (Winkler, 1991; glej tudi Winkler, 1999), vendar je bilo v luči zlasti socialnogeografskih pristopov nekompleksno in morda prav zaradi tega dostikrat neuspešno. Obsežne analize prizadevanj za družbeno integracijo Romov, ki so poudarjala zlasti segmente izobraževanja in zaposlovanja (Smerdu, 1999), se pogosto vračajo k problemu sklenjenega kroga, katerega ključne točke predstavljajo 
prav bivanje, delo in izobrazba (Žugel, 1991). Hvalevredni poskusi vendarle - sicer mnogo prepočasi -dajejo nekaj rezultatov (Žagar N., 1999). Projekte in programe, kakršen je bil npr. »Romske ženske to zmoremo« in pa mnogo širši »Poklicno informiranje in svetovanje« (Žagar, Klopčič, 2006) bi zato veljalo nadaljevati.

Namen tega prispevka je podati temeljne elemente prostorske razmestitve romskega prebivalstva, njihovega načinov bivanja in problemov, ki nastajajo znotraj t.i. »romskih naselij« in na njihovem zunanjem robu, na območju socialnega in prostorskega stika z ostalim prebivalstvom. Ti odnosi se lahko hitro - kot so pokazali prav dogodki v zadnjih treh letih prelevijo od latentne konfrontacije v odprt konflikt. Na ta način želimo osvetliti v geografskih krogih očitno manj poznano tematiko in morda vzpodbuditi sorodne lokalne raziskave, ki bi ne le izboljšale vedenje o posameznih naseljih, temveč tudi v splošnem lahko bistveno prispevale tudi $\mathrm{k}$ učinkovitejšim politikam na tem področju.

\section{K METODOLOGIJI PROUČEVANJA PROSTORSKIH VIDIKOV ROMSKIH NASELIJ}

Pomanjkanje izkušenj in razmeroma slaba proučenost kompleksa romskih naselij in naselbinskih enot marginalnih družbenih skupnosti v Sloveniji nasploh je izhodiščna popotnica vsakemu, ki se bo želel spopasti s to zanimivo tematiko. Tuje izkušnje so nam lahko le v skromno pomoč, saj smo v dosedanjih razpravah in terenskih raziskavah odkrili precejšnjo individualnost teh naselbin in velike razlike med njimi že v Sloveniji. To velja še posebej, ko se od proučenih dejstev in analiz spravimo h konceptom razvoja. Med državami se močno razlikujejo in s posnemanjem npr. italijanskih ali madžarskih zgledov bi utegnili zanemariti prav omenjeno lokalno in individualno naravo romskih naselij. Kljub temu pa je mogoče vrsto elementov vendarle spraviti na skupni imenovalec in s primerjavo izoblikovati jasnejša stališča ter ugotoviti nekatere skupne poteze.

Proučevanje prostorske problematike romskih naselij je značilen primer, ko posplošeni pristopi ne pomagajo prav veliko. Politična geografija se problemov marginalnih skupnosti loteva zelo obrobno. Temu je nemara kriva pretežno globalistična naravnanost sodobnih političnogeografskih in geopolitičnih pristopov, ki pa se po drugi strani zaradi naraščajoče družbene stratifikacije in tudi s tem povezane politične polarizacije morajo soočati tudi $\mathrm{z}$ marginalnimi skupinami (v svetovnem okviru to nikakor niso le Romi). V slovenski politični geografiji, ki ima močne temelje tudi v socialni geografiji srednjeevropske tradicije, smo precej na boljšem. Socialnogeografska šola je s poudarjanjem podrobnih terenskih raziskav, vključujoč pri tem prostorske razmere, potekajoče procese in odnose med različnimi dejavniki v proučevanem okolju ter ne nazadnje tudi ugotavljanjem problemov. Pri tem ima pomembno mesto tudi uporaba terenskih indikatorjev, saj je statističnih podatkov o romskih naseljih premalo, dinamika spreminjanja razmer pa hitra in jih službe, ki se jim posebej posvečajo, komaj sledijo. Na pomanjkanje podatkov in probleme $\mathrm{z}$ dostopnostjo le-teh je treba torej računati kot s precej standardno težavo.

Zato je temelj novih spoznanj o sodobni strukturi, problemih in perspektivah Romov in njihovih naselbinskih enot potrebno terensko delo. Le-to pa ima nekaj posebnosti, ki jih 
je nujno treba upoštevati, če hočemo doseči realno sliko razmer. To so potrdile tudi nedavne izkušnje $s$ terenskim delom študentov politične geografije. Srečali smo se $s$ tremi občinami z romskimi naselji: Grosuplje, Dobrovnik in Krško. V vseh primerih je bilo potrebno najprej temeljite priprave: čim podrobnejša seznanitev z okoljem in predhodnimi rezultati ter - kar je morda najpomembnejše - tudi obvestilo vseh potencialnih sogovornikov na terenu. Potrebno je vzpostaviti zaupanje in šele potem preiti $v$ terenski posnetek $z$ anketiranjem intervjuvanjem, kartiranjem, fotografiranjem in drugimi načini zajema terenskih podatkov. Da bi zagotovili kar najbolj verodostojno sliko, je smiselno pristopiti s treh strani: Romov, okoliškega prebivalstva in različnih institucij, kot so na primer šole, vrtci, občinska uprava, občinski svet, romski svetnik, zavod za zaposlovanje, zavod za socialno varstvo, zdravstvene ustanove, policija, cerkev, humanitarne organizacije, nevladne organizacije in podobno. Na ta način dobimo čimbolj kompleksen pregled nad stanjem in lažje izločamo tendenciozne odgovore, ki jih utegnemo dobiti pri eni od proučevanih strani.

Predmet geografskega proučevanja romskih naseljih je najprej lokacija romskega naselja: lega glede na ostali del naselbinskega sistema, odnos do okoljskih prvin in podobno. Sledi proučitev strukture naselja, kjer hitro izstopita dva problema: kakovost stavbnega fonda in komunalna urejenost ter opremljenost, posredno pa tudi formalna urejenosti (legalnost). Tako smo že sredi opaznih problemov predvsem socialne narave in demografske analize, od starostne in spolne sestave, prek izobrazbe do zaposlenosti in ekonomskih virov preživetja. Tretji sklop predstavljajo odnosi, kjer nas bolj kot percepcija zanimajo dejanske povezave in ločnice, ki se vzpostavljajo v lokalnem okolju, ter seveda razlogi zanje. Posebno mesto je smiselno odmeriti tudi vprašanju organizacije in identitete, $s$ tem pa tudi jezika in kulture: tematik, ki so bili doslej nasploh močno v senci zgolj »problemsko« orientiranih študij, Romi pa prepoznavni predvsem (če ne celo izključno) zgolj po socialnih problemih in težavah v sosedstvu. Medtem ko kar nekaj sodobnih avtorjev o romski tematiki vztrajno izpostavlja njihovo zapostavljenost, krivice, nestrpnost, pa celo rasizem in ksenofobijo, je treba že v začetku jasno povedati, da te teze večinoma le podaljšujejo življenjsko dobo stereotipov o Romih in romskih naseljih in potiskajo to prebivalstvo prav v družbeno obrobje. Žal pogosto prezrejo sodobne procese in ne uspejo zaznati niti perspektiv in niti pasti, ki se s hitro družbeno dinamiko pojavljajo tudi v romskih naseljih.

\section{ROMI: AVTOHTONA MANJŠINA ALI ZGOLJ ETNIČNA SKUPNOST}

Poreklo Romov ostaja - kljub številnim zapisom - še vedno precej nejasno in zato po eni strani argument marginalizacije (Romi nimajo kodificiranega jezika in zato tudi ne zapisane zgodovine), po drugi pa priložnost mitologizacije. Kljub veliki prostorski razpršenosti Romov po Evropi (ocenjujejo jih na okrog 14 milijonov) in posledično znatni kulturni raznolikosti imajo zanesljivo vsaj eno skupno značilnost: povsod predstavljajo marginalne družbene skupine, ne glede na lastnost teritorija in njihovo regionalno in državno številčnost (Jezernik, 2006, 8-18). 
V slovenskem okviru se je ob priliki uveljavljanja posebnega zakona o romski skupnosti prav zaradi očitkov o nedokazani tradicionalni prisotnosti vnela precej ostra razprava o avtohtonosti Romov. V želji po pravnem izenačenju s pripadniki madžarske in italijanske skupnosti je to nujno (skladnost z ustavo). Sprejem posebnega zakona o Romih bo te šele zares postavil v vlogo manjšine: vzpostavil bo nove odnose na področju kulture, političnega življenja in gospodarsko-socialnih ter končno tudi prostorskih odnosov. Na tem področju pa se skladno z dosedanjimi praksami srečamo s kriterijem avtohtonosti, ki je eden od merodajnih instrumentov dodeljevanja različnih podpor in razpisov. Čeprav je v slovenski družbi in tudi med raziskovalci deljeno mnenje, ali avtohtonost (Romov) sploh omenjati, je v korist tega početja treba izpostaviti vsaj dva argumenta: avtohtonost kot ustavno kategorijo in drugič kot povsem pragmatično rešitev. Kako je torej z avtohtonostjo Romov v Sloveniji?

Ta ustavna kategorija se zdi v primeru italijanske in madžarske manjšine zaradi njihove jasne historične topografske določenosti pač dovolj preprosta in uporabna. Na naselje natančno lahko namreč določimo območje avtohtone poselitve, ki ima izjemno pomembno politično kompetenco: določeno ozemlje, na katerem veljajo izrecne manjšinske pravice (topografija, izobraževanje, kulture, organiziranost idr.). V primeru Romov pa je drugače. V več besedilih jih obravnavajo kot »neteritorialno« skupnost, kar pa je iz geografskega zornega kota nesmisel. Gre za razpršeno ali sporadično poselitev. Zato naj bi bilo težko določiti območja avtohtone poselitve. V Zakonu o lokalni samoupravi so opredeljene občine, za katere veljajo tam obstoječe romske naselbine kot avtohtone. Ta formulacija lahko v posameznih primerih povzroči kar nekaj težav: občine z neavtohtonimi Romi bi naj ne imele možnosti kandidature za sredstva urejanja romskih naselij. Realno pa je drugače. Romi so v času (fazi) nomadskega ali polnomadskega načina življenja »krožili« na širšem ozemlju, toda držali so se večinoma nekih regionalnih okvirov. Določiti je mogoče kraje, kjer so imeli urejene osnovne pristojnosti (npr. izdaja osebnih dokumentov, mesto šolanja ipd.). Taki zapisi in pričevanja obstajajo, z družinskimi imeni / priimki. V strnjeni obliki prinaša večino teh navedb delo Pavle Štrukelj (2004). Zaradi tega avtohtonost tega prebivalstva ni sporna. Zelo težko pa avtohtonost dokazujemo z elementi trenutnega prostora poselitve, ki je večidel rezultat stalne naselitve mnogo pozneje, kot pa se je politično oblikoval slovenski narod in ko lahko tudi štejemo kot element etnifikacije Romov. Povsem neprimerno je tudi iskanje individualne avtohtonosti, saj bi zahtevala vrsto preiskav, kar pa ni dopustno. Narodna / etnična opredelitev je osebna izbira, ki pa se lahko realno uresničuje predvsem na kolektivni naravi in teritorialni navezanosti. Zato je smiselneje upoštevati regionalni in ne zgolj ozki lokalni okvir. Lokalno bo v tem primeru razmeroma težko ugotavljali avtohtonost Romov, še težje pa reševati zapleteno problematiko urejanja prostorskih problemov. Z dvigom socialne ravni in uspešno integracijo lahko pričakujemo povečano prostorsko mobilnost, eno od temeljnih značilnosti človeka postmoderne družbe in obenem tudi svoboščino, na katero prisegamo vsi. To niti najmanj ne izničuje teritorialne ali tudi lokalne navezanosti, ki ostaja izhodišče, ne nujno pa tudi cilj sodobne naselitve Romov. Tako kot vsem je tudi njim lahko postaja na življenjski poti.

Pragmatičnost upoštevanja kriterija avtohtonosti pa je odprt evropski prostor znotraj EU, pa tudi širše. Odsotnost te omejitve bi bila lahko privlačen motiv za morebitna doseljevanja večjih skupin romskega prebivalstva predvsem z Balkanskega polotoka. V tej luči je treba omeniti tudi dejstvo, da Romi zaradi odsotnosti lastne države nimajo države zaščitnice; nimajo 
torej »matice«, ki bi jim nudila institucionalno podporo. Vrh vsega se romske skupine med seboj precej razlikujejo po jeziku, verskih opredelitvah in končno tudi kulturni artikulaciji, kljub nespornim nekaterim skupnim potezam. Skupine Romov, ki so dalj časa živele na določenem (nekoliko širšem) teritoriju in se tam tudi oblikovale (in seveda tudi prispevali k oblikovanju - vsaj v omejenem obsegu) kulturne pokrajine. Zato je kljub ohlapnosti termin »avtohtonost« smiselno navajati kot regionalno in ne zgolj lokalno kategorijo.

Avtohtonost je izhodišče tudi uživanja nekaterih posebnih pravic, ki so jih sicer deležni Italijani in Madžari. To je na primer tudi funkcija romskega svetnika. Po določilih novele Zakona o lokalni samoupravi (ZLS-L, 14. člen in 101a člen) imajo obvezo romskega svetnika naslednje občine: Beltinci, Cankova, Črenšovci, Črnomelj, Dobrovnik, Grosuplje, Kočevje Krško, Kuzma, Lendava, Metlika, Murska Sobota, Novo Mesto, Puconci, Rogašovci, Semič, Šentjernej, Tišina, Trebnje, Turnišče. Do sedaj se temu izogiba le občina Grosuplje, kljub odločbi Ustavnega sodišča (Odločba US, U-I-345/02).

\section{ROMSKA NASELJA}

Pri obravnavi vprašanja prostorske mobilnosti Romov se moramo vrniti k pojavu in značilnostim romskih naselij. V programih in projektih, namenjenim izboljšanju stvarnega položaja Romov, je navadno govora predvsem o bivalnih razmerah. Vendar je pojem »romsko naselje« oziroma prostorski problemi bistveno širši in zajema celotno območje, na katerem Romi opravljajo različne funkcije.

Izraz »romsko naselje« je nastal v določeni zadregi, kako poimenovati skupino bivalnih enot, zasedenih z romskim prebivalstvom. Te enote niso dejanska statistična naselja z ustrezno numeracijo; pogosto niti nimajo hišnih številk. Čeprav so v bližini obstoječih statistično opredeljenih naselij, se vanje funkcionalno večinoma ne vključujejo. Tudi v tem gre iskati razloge za številne probleme legalizacije tovrstnih naselbin oziroma posameznih bivalnih enot. Vendar je po drugi strani evidenca romskega prebivalstva dokaj jasna, posebej če uporabimo sezname prejemnikov določene socialne in zdravstvene pomoči, šolske obveznike ali pa volilne imenike. Romi so prostorsko razpršena skupnost, ki so v teku zadnjih desetletij zaradi načrtne ustalitve in drugih - večinoma $\mathrm{z}$ modernizacijo povezanih razlogov, izoblikovali več t.i. »romskih naselij«, v katerih živi večji del pripadnikov. Največ jih živi v Prekmurju in na Dolenjskem. Pavla Štrukelj omenja v svoji monografiji 60 romskih naselij in zaselkov v 17 občinah v Prekmurju, 56 naselij v 13 občinah na Dolenjskem in v Beli krajini ter 8 zaselkov Sintov (največkrat imenovanih tudi »gorenjski« Romi) na Gorenjskem (Štrukelj, 2004, 303309). Slednjih je komaj nekaj odstotkov. Romi so večidel podeželsko prebivalstvo. Povsem nova skupina so mestne populacije v večjih mestih, predvsem v Ljubljani in Mariboru; slednji so večinoma imigranti iz držav nekdanje Jugoslavije, ki so prišli v slovenski prostor v zadnjih treh desetletjih. Deloma se jim pridružujejo tudi begunci in azilanti iz istih območij, ki se priseljujejo zaradi težkih domačih razmer.

Dosedanja terenska proučevanja in analize statističnih podatkov dokazujejo, da živi največji del - nad 40 \% - v Prekmurju, okrog tretjine pa na Dolenjskem - »dolenjski« Romi. Sintov (največkrat imenovanih tudi »gorenjski« Romi) je le nekaj odstotkov, prav tako pa tudi izrazito mestnih populacij v Ljubljani in Mariboru; slednji so večinoma imigranti iz držav 
nekdanje Jugoslavije, ki so prišli v slovenski prostor v zadnjih treh desetletjih (Zupančič, Repolusk, Josipovič, 2001). Romska naselja so večinoma mlajšega nastanka, saj je stalna naselitev uspela $\mathrm{v}$ veliki meri šele $\mathrm{v}$ sedemdesetih letih. Že prvotna naselitev v poznem srednjem veku je zadela na razmeroma gosto naseljeno pokrajino, kjer so se lahko le razpršili: koncentracije niso bile mogoče. Poleg tega so jih pogosto preganjali pod različnimi pretvezami, tako da se je nomadski način življenja zadržal globoko v moderno dobo. Že v 18. stoletju so bili na prostoru nekdanje Habsburške monarhije za časa Marije Terezije izpeljani poskusi stalne naselitve, ki pa skoraj niso imeli uspeha. Poznejše naselitve, povezane tudi s precej nasilnimi ukrepi, prav tako večinoma niso imele trajnejšega učinka. Vendar pa so bili Romi vsaj delno »teritorializirani«; registrirani so bili na ozemljih določenih občin, čeprav niso stalno bivali na enem kraju, temveč so se zaradi preživljanja (opravljanja različnih »potujočih« obrti) selili. Tudi načrtne stalna naselitve (in preselitve) Romov na različne kraje večinoma niso trajno uspeli: že čez kakšno leto je večina »preseljencev« prišla nazaj. Vendar pa se je ob prej omenjeni »teritorializaciji« vendarle določen del Romov pričel prostorsko ustaljevati. Zlasti prekmurski Romi so se v precejšnji meri vsaj močno lokalizirali, a hitro tudi za stalno naselili. Nomadizem je pri njih postopoma postajal zgolj še folklora (Štrukelj, 1979, 80-98). Stalnejša naselitev je dejansko uspela šele po močnih socialnih spremembah in modernizacijskih procesih, ki so tudi sicer močno spremenili način življenja podeželskega prebivalstva. S stalno naselitvijo so jim bile vsaj deloma dostopne nekatere dobrine vse bolj urbanizirane in modernizirane družbe. Toda stalna naselitev se je hitro izkazala za nadaljevanje obrobnega družbenega položaja tudi v novih razmerah. Socialni preboj in s tem doseganje ravni večinskega prebivalstva se je posrečil le redkim. Stalna naselitev je bila - prostorsko gledano - največkrat omejena na eno samo družino. Kasneje se je ta zaradi porok in visoke rodnosti precej razširila, neredko pa so se tja naselili še bližnji in / ali daljni sorodniki, tako da so romska naselja dobila nekatere strukturne in fiziognomske posebnosti. V pomanjkanju lastništva zemlje in pravnih regulativ, finančnih sredstev in tudi vrednostnega sistema so bile gradnje zelo različne, večinoma pa slabših kvalitet. Ker so se locirali na robna ter v splošnem manj kakovostna območja in so bili tudi gradbeni materiali zelo raznoliki in marsikdaj slabi, so tudi romska naselja postala odkrit »slum«.

Po zadnjem statističnem popisu leta 2002 je bilo v Sloveniji 3264 Romov, kar je - za razliko od večine ostalih popisnih kategorij - razmeroma visok porast. Vendar to dokazuje le del romske populacije, ki jo je na podlagi ocen poznavalcev, podatkov Zavoda za socialno varstvo in drugih ustanov, mogoče oceniti na okrog 7000 (Komac, Zupančič, Winkler, 1999), nekateri pa celo do okrog 10.000, ki jo je mogoče na podlagi podatkov socialnih služb opredeliti kot dokaj realno (Horvat, 1999). Danes smo bližje zadnji številki Statistični popisi naj bi dajali zato močno podcenjeno sliko o številčnosti Romov. V Sloveniji Romi predstavljajo po številu torej podobno majhno etnično skupnost, kot sta italijanska in madžarska manjšina. Vendar se po večini demografskih, socialnih, naselitvenih, pa tudi pravnih in ekonomskih značilnostih od obeh manjšin močno razlikuje. Romi so namreč prostorsko razpršena skupnost, ki so v teku zadnjih desetletij zaradi načrtne ustalitve in drugih - večinoma $\mathrm{z}$ modernizacijo povezanih razlogov, izoblikovali več t.i. »romskih naselij«, v katerih živi večji del te skupnosti. Natančnejše določanje gostote romske poselitve otežkoča visoka stopnja prostorske razpršenosti in nestalnost etničnega opredeljevanja (očitno se opredeljujejo glede na družbeno okolje, še posebej tisti, ki so že dosegli izobrazbo in potem določen socialni 
dvig). S tem v zvezi je treba podčrtati, da je v tej luči opredeljevanje po narodni pripadnosti za osebe, ki so izvorno Romi (potomci romskih staršev), prvenstveno stvar socialne in ne etnične stratifikacije. To pa »statistično« zopet ustvarja Rome kot izrazito marginalno populacijo, $\mathrm{s}$ čimer se pri njih samih poglabljajo občutki družbene obrobnosti.

Romsko prebivalstvo v Sloveniji je jezikovno in kulturno precej heterogeno. Že delitev na »prekmurske« - večinoma t.i »vlaške« Rome, »dolenjske« Rome in Sinte (ali tudi »gorenjske« Rome), pove, da imamo opraviti ne le z medregionalnimi razlikami, temveč tudi z občutnimi razlikami v poteku selitvenih tokov in družbeno-kulturnem razvoju (Štrukelj, 1979). Te opredelitve imajo potem še eno posledico: zaradi zmanjšanega števila se ustvarja tudi - verjetno napačna - predstava o poselitvenih značilnostih romske populacije. Zato lahko ugotavljamo predvsem tisti del romske populacije, ki s svojim načinom življenja in s tem povezanim specifičnim prostorskim obnašanjem kaže na obseg romskega prebivalstva.

\section{OBLIKOVANJE ROMSKIH NASELIJ KOT POSEBNEGA PROSTORSKEGA POJAVA $\vee$ SKLOPU NASELBINSKEGA SISTEMA SLOVENIJE}

V Sloveniji je po dosedanjih evidencah 105 (MOP) t.i. romskih naselij. Poleg teh je še kakih 20 do 25 manjših zaselkov, v katerih tudi prebivajo Romi. Skupno lahko torej ocenimo število vseh romskih naselbinskih enot do okrog 130 z okrog 9000 stanovalci. Vendar je število Romov nekoliko večje in po vsej verjetnosti moramo ocenjevati na nekaj nad 10.000. Med 2 miljonoma prebivalcev in 6.000 naselij (rednega in stalnega naselbinskega sistema Slovenije) oba podatka kažeta na sorazmerno majhno število. Toda v kontekstu po eni strani manjšinskega vprašanja in po drugi v luči urejanja specifičnih problemov romskih naselbin je - še posebej pa $\mathrm{v}$ regionalnem in lokalnem kontekstu - to vprašanje več kot potrebno pozornosti.V pričujočem zapisu želimo opozoriti predvsem na izgled, strukturo in funkcije romskih bivalnih enot $\mathrm{v}$ tradicionalnem in modernem kontekstu. Posebej je treba omeniti tudi pogosto povsem zanemarjen vidik romske materialne kulturne dediščine.

Romska naselja so večinoma mlajšega nastanka, saj je stalna naselitev uspela v veliki meri šele v sedemdesetih letih. V Prekmurju je bila stalna naselitev sicer nekoliko starejša (že na prelomu iz 19. v 20, stoletje), a njihovi stanovalci so bili pogosto sezonski (ali podobno) migranti (sezonstvo je bilo pogosto tudi med slovenskimi Prekmurci). Že prvotna naselitev v poznem srednjem veku je zadela na razmeroma gosto naseljeno pokrajino, kjer so se lahko le razpršili: koncentracije niso bile mogoče. Poleg tega so jih pogosto preganjali pod različnimi pretvezami, tako da se je nomadski način življenja zadržal globoko v moderno dobo. Že v 18. stoletju so bili na prostoru nekdanje Habsburške monarhije za časa Marije Terezije izpeljani poskusi stalne naselitve, vendar skoraj brez uspeha. Poznejše naselitve, povezane tudi s precej nasilnimi ukrepi, prav tako večinoma niso imele trajnejšega učinka. Vendar so bili Romi vsaj delno »teritorializirani«; registrirani so bili na ozemljih določenih občin, čeprav niso stalno bivali na enem kraju, temveč so se zaradi preživljanja (opravljanja različnih "potujočih« obrti) selili. Tudi načrtne stalna naselitve (in preselitve) Romov na različne kraje večinoma niso trajno uspeli: že čez kakšno leto je večina »preseljencev« prišla nazaj. Vendar 
pa se je ob prej omenjeni »teritorializaciji« vendarle določen del Romov pričel prostorsko ustaljevati. Zlasti prekmurski Romi so se v precejšnji meri vsaj močno lokalizirali, a hitro tudi za stalno naselili. Nomadizem je pri njih postopoma postajal zgolj še folklora (Štrukelj, 1979, 80-98). Stalnejša naselitev je dejansko uspela šele po močnih socialnih spremembah in modernizacijskih procesih, ki so tudi sicer močno spremenili način življenja podeželskega prebivalstva. S stalno naselitvijo so jim bile vsaj deloma dostopne nekatere dobrine vse bolj urbanizirane in modernizirane družbe. Toda stalna naselitev se je hitro izkazala za nadaljevanje obrobnega družbenega položaja tudi v novih razmerah. Socialni preboj in s tem doseganje ravni večinskega prebivalstva se je posrečil le redkim. Stalna naselitev je bila - prostorsko gledano - največkrat omejena na eno samo družino. Kasneje se je ta zaradi porok in visoke rodnosti precej razširila, neredko pa so se tja naselili še bližnji in / ali daljni sorodniki, tako da so romska naselja dobila nekatere strukturne in fiziognomske posebnosti. V pomanjkanju lastništva zemlje in pravnih regulativ, finančnih sredstev in tudi vrednostnega sistema so bile gradnje zelo različne, večinoma pa slabših kvalitet. Ker so se locirali na robna ter v splošnem manj kakovostna območja in so bili tudi gradbeni materiali zelo raznoliki in marsikdaj slabi, so tudi romska naselja pogosto postala odkrit »slum«. Kakšna so torej romska naselja?

Najprej je treba potrditi, da upravičeno govorimo o »romskih« naseljih. Kot že večkrat poudarjeno, smo pri izrazu »naselje« v zadregi, saj ta oznaka formalno ni pravilna - hišne številke, ki so jih tudi ne glede na pogoje »legalnosti« večinoma dobili, jih vključujejo v druga (redna) naselja naselbinske mreže v Sloveniji. Večinoma so locirani na robu naselij ali zunaj siceršnjih naselij. Le v nekaj primerih (le kakih 10\%, na primer Pušča pri Murski Soboti, Žabjek pri Novem mestu, Vranoviči pri Črnomlju, Hudeje pri Trebnjem, Černelavci in druga) so to večja naselja z več sto prebivalci. Večinoma gre za čista romska naselja; pripadnikov drugih skupin (skoraj) je med njimi le za vzorec. Razporeditev hiš in ostalih poslopij (kolikor jih je) je stihijska, brez načrta in izbranih arhitekturnih prvin. Videti so, kot da je bila improvizacija pri izbiri lokacije, materialov in tudi same gradnje pomembno vodilo. Ker Romi večinoma niso razpolagali s posestjo, živino in drugimi materialnimi prvinami gospodarskega preživetja, se pri nastajanju niso dosti ozirali za prihodnjimi možnostmi morebitnega gospodarskega razvoja. Stihijskost se je kmalu maščevala, najprej pri komunalni opremljenosti. Manjša romska naselja so navadno nastala s priselitvijo ene družine, ki se je potem po porokah, zvezah in zaradi visoke rodnosti okrepila in povečala. Stihijskost je podobna kot pri prej omenjenem naselitvenem tipu. Zametek naselja je bila lahko tudi opuščena hiša ali gospodarsko poslopje, ki so ga potem naselili Romi. Gradnje so po kakovosti zelo različne. Pletenih »butanic«, kot jih v svoji monografiji še omenja Štrukljeva (1979), praktično ni več (ali pa zanje ne vemo!). Uveljavile so se zlasti lesene barake, ki so jih ponekod dograjevali še z drugim priročnim materialom. Toda v nekaterih okoljih se je ob zaposlenosti in drugih virih dohodkov stanovanjski standard bistveno izboljšal. Posebej tam, kjer je ob sodelovanju Romov in lokalne skupnosti prišlo do urejanja teh naselbin in tako tudi posameznih hiš, se po zunanji fiziognomiji romske naselbine komaj kaj ločijo od ostalih naselij. Ponekod so postavili industrijsko narejene zabojnike. $\mathrm{V}$ to kategorijo bi lahko postavili tudi stare železniške vagone in druga podobna bivališča. Romska naselja, ki so del naselbinske mreže večinskega prebivalstva, navadno predstavljajo iz različnih razlogov izpraznjeni stanovanjski fond, ki so ga Romi naselili, ali pa je ta predstavljal le začetek osnovanja romskega naselja, ki so ga popolnjevali z nakupom novih 
zemljišč, prevzemom zemljišč neromske populacije. Praviloma so se držali že zgrajenih poti in cest, kjer so nove hiše nastajale blizu le-teh. Neredko se tudi zgodi, da naselje za več let zapustijo, kasneje pa ponovno naselijo. Te menjave so mnogo pogosteje tam, kjer je stavbni fond po kakovosti skromen (lesene barake, pločevina in podobni materiali, ali pa gre za velike zabojnike in različne montažne elemente) in kjer preselitvi botrujejo še drugi razlogi, kot so na primer zapleteni odnosi med romskimi skupinami (naselji) ali pa konflikti z domačim prebivalstvom. Vidimo torej, da so romske skupnosti danes pretežno lokalizirane, relativno trajne glede naselitve v prostoru, največkrat stihijskega nastanka, pogosto anarhičnega videza ter komunalno neurejena. To pa so že tudi elementi, ki sprožajo z okoliškim prebivalstvom vrsto napetih situacij, obenem pa tudi pejorativizacijo romskih naselij in njihovih stanovalcev.

\section{LOKACIJE ROMSKIH NASELIJ}

Ustaljevanje naselitve je med Romi trajalo več stoletij in se je v Sloveniji končalo šele v osemdesetih letih 20. stoletja. Vendar imamo tudi še danes posamezne primere preselitev zaradi različnih razlogov. Skromne ekonomske možnosti Romov so ob odsotnosti državnih konceptov vodile $\mathrm{v}$ precejšnjo stihijskost glede izbire kraja stalnega bivališča. Romi so praviloma izbirali zemljišča, ki so bila pač še na razpolago oziroma tam, kjer je bil odpor domačega prebivalstva relativno manjši. V mnogih primerih je prišlo do uzurpacije zemljišč in praktičnega priposestvovanja. Zaradi nagle demografske rasti in oblikovanja novih družin ter ob hkratnih sporih znotraj romskih skupnosti so se manjše skupine odcepljale in tvorile nova naselja. Tako se je oblikovala značilna drobnonaselbinska struktura romskih naselij. To je mogoče razumeti tudi kot prilagoditev na skromne razpoložljive vire preživljanja, ki so ob nomadizmu manjših skupin vodile k prostorski razpršenosti. Tako je dobra polovica romskih naselbin dejansko zaselkov in malih naselij z manj kot 50 prebivalci. Le 7 jih ima več kot 200 in od tega dva več kot 500 prebivalcev (Pušča v Prekmurju in Brezje-Žabjek pri Novem mestu *po nekaterih podatkih, po drugih ne). Med 100 in 200 prebivalci je 12 naselij z romskim prebivalstvom. Čeprav so romska naselja nastajala stihijsko, je mogoče s primerjalno analizo ugotoviti nekatere skupne značilnosti. To so predvsem naslednje:

- $\quad$ naselja so se oblikovala v bližini centralnih krajev (ker so dajala več priložnosti za preživetje),

- $\quad$ pogosto so izbirali bližino odlagališč odpadkov (zaradi možnosti zbiranja sekundarnih surovin),

- $\quad$ pogosteje so izbirali bližino kulturno-jezikovnih stikov in multietničnih okolij (zato je romskih naselij precej prav v robnih predelih),

- naselili so izpraznjena stalna ali začasna bivališča ter »cenejši« že delno devastiran prostor (npr. izpraznjene kočevarske vasi, kamnolomi ipd.),

- $\quad$ iskali so bližino vodnih virov, kar je v nekaterih primerih privedlo tudi do konfliktnih naselbinskih situacij.

Skoraj dve tretjini romskih naselbin je fizično ločenih od ostalih naselij in tvorijo homogene naselbinske enote $\mathrm{z}$ značilnim izgledom. Šestina jih je spojenih z naselji, okrog 
četrtine pa je mestnih naselij; locirane so predvsem na robu urbanih naselbinskih enot. Sicer so romska naselja predvsem podeželski pojav (tri četrtine) in še posebej v perifernih območjih (okrog dveh petin). Regionalno se vežejo predvsem na subpanonski predel Slovenije: Belo krajino, Dolenjsko s Posavjem in Prekmurje. Drugod jih je manj, izvzemivši novejše romske imigrante z Balkanskega polotoka, ki so se skoncentrirali predvsem v Ljubljani in Mariboru. Najbolj razpršeno so naseljeni Sinti, dostikrat imenovani tudi »gorenjski«ali »srednjeevropski« Romi (sami se nimajo za Rome, temveč za povsem samosvojo etnično skupnost). Večina jih živi na zgornjem Gorenjskem med Kranjem in Jesenicami. Po ocenah jih je okrog 150 (Bivalne razmere Romov po občinah v Sloveniji, Urad RS za narodnosti, 2004-2005, interno gradivo).

\section{OBLIKE ROMSKIH NASELBIN}

Za Rome je torej značilna prostorska razpršenost in bivanje v relativno zaključenih »romskih« naselbinah. Mnoga bi povsem upravičila ime etničnega in socialnega geta, po svoji fiziognomiji, strukturi in tudi funkciji pa so te naselbine ali deli naselbin izraziti »slumi«. Prav obe omenjeni potezi jih uvrščata med socialno ogrožene in marginalne družbene skupine oziroma skupnosti, po drugi strani pa prav zaradi tega značaja pogosto prihaja do konfrontacij in konfliktov z ostalim prebivalstvom. Razlikujemo več tipov naselij z Romi:

- $\quad$ samostojno stoječa romska naselja, ki so statistično (upravno) del ostalih naselij, vendar so od njih prostorsko ločeni (zaselek) in zgrajeni praviloma v povsem drugačnem gradbenem in arhitekturnem stilu. Značilna so predvsem za podeželska naselja.

- $\quad$ romska naselja kot del ostalih naselij, vendar združena na enem delu (vaška ulica). V gradbeni strukturi prevladujejo bivalno manj kvalitetne stavbe; ti deli naselij so praviloma najslabše komunalno opremljeni deli naselij.

- $\quad$ mestne romske »četrti« so locirane predvsem v starih delih mest, ki jih je zaradi slabše kakovosti prejšnje prebivalstvo pač zapustilo, ali pa zasedajo predvsem sive mestne cone neuporabljenega prostora poleg industrijskih četrti in na drugih manj atraktivnih lokacijah. Praviloma jih sestavljajo različne improvizirane bivalne enote. Te predele v glavnem naseljuje priseljeno romsko prebivalstvo (iz območij nekdanje Jugoslavije).

- $\quad$ posamične hiše ali druge stanovanjske enote $v$ podeželskih (redkeje) ali mestnih naseljih (Zupančič, 2003).

Gradnje so po kakovosti zelo različne. Zelo pogoste so lesene barake, ki so jih ponekod dograjevali še z drugim priročnim materialom. Precej je tudi zidanih hiš. Ponekod so postavili industrijsko narejene zabojnike. Drugje (zlasti v mestnih naseljih) so prevzeli izpraznjeni stanovanjski fond. Praviloma so se držali že zgrajenih poti in cest, kjer so nove bivalne enote nastajale blizu le-teh. Neredko se tudi zgodi, da naselje za več let zapustijo, kasneje pa ponovno naselijo. Te menjave so mnogo pogosteje tam, kjer je stavbni fond po kakovosti skromen (lesene barake, pločevina in podobni materiali, ali pa gre za velike zabojnike in različne montažne elemente) in kjer preselitvi botrujejo še drugi razlogi, kot so na primer zapleteni odnosi med romskimi skupinami (naselji) ali pa konflikti z domačim prebivalstvom. 
Razporeditev hiš in ostalih poslopij (kolikor jih je) je stihijska, brez načrta in izbranih arhitekturnih prvin. Ker Romi večinoma niso razpolagali s posestjo, živino in drugimi materialnimi prvinami gospodarskega preživetja, se pri nastajanju niso dosti ozirali za prihodnjimi možnostmi morebitnega gospodarskega razvoja. V smislu gospodarske osnove so se - pogosto v veliko nasprotovanje okoliških prebivalcev - najbolj uveljavili kupi sekundarnih surovin, posebej kovine, njihovo pridobivanje, sortiranje, preprodaja in odlaganje.

Poseben problem predstavlja tudi nastajanje novih naselij. Ker so stare naselbine prostorsko omejena, so zlasti mlajše generacije pogosto prisiljene iskati nov bivalni prostor: pogosto tako kot njihovi starši, torej ilegalno.

\section{OPREMLJENOST ROMSKIH NASELIJ}

Potek stalne naselitve, mikrolokacije in razporeditev romskih naselij posebej izpostavlja enega najbolj perečih problemov: pomanjkljive komunalne opremljenosti in na splošno slabo gradbeno strukturo. Romska naselja so pogosto pravi »slumi«, z prevladujočo odsotnostjo prostorske dokumentacije za raven teh naselbin in prav tako za večji del posameznih bivališč. Po podatkih, pridobljenih $\mathrm{z}$ anketo marca 2007 je pomanjkanje osnovne komunalne infrastrukture, se pravi dostopnost pitne vode in električne energije še vedno zelo očiten in razširjen problem. Petina romskih naselij je še praktično brez teh dobrin. Pri tem izstopajo razlike med romskimi naselji na Dolenjskem (s Posavjem in Belo krajino) in Prekmurjem; čeprav se po gradbeni strukturi ne razlikujejo zelo veliko, so na Dolenjskem precej slabše opremljena. Še skoraj polovica jih je brez urejene oskrbe z električno energijo, nič dosti bolje pa ni tudi z vodno oskrbo. V Prekmurju je še znaten del - skoraj polovica - romskih naselij vezana na lokalne vodne vire. To so navadno lastna črpališča podtalnice in studenci, ki pa niso posebej izdatni. Na Dolenjskem je spričo prevlade kraškega sveta precej naselij vezanih na dovažanje vode z gasilskimi cisternami. Nekateri so si postavili male plastične cisterne. Problem pri romskih naseljih je posebej oskrba z električno energijo. Črne gradnje (ki seveda prevladujejo) praviloma ne dobijo soglasij podjetij za distribucijo električne energije, zato si jo postavijo »na črno«, z nezanesljivimi povezavami npr. od sosedov. Take rešitve niso varne in je precej možnosti, da pride do nesreč in požarov. Zaradi neplačevanja stroškov so pogosti tudi izklopi. Da bi dosegli minimum potrebne oskrbe, uporabljajo zasebne male agregate na motorni pogon.

Večina romskih naselij ima sedaj soliden prometni dostop. Ker so romska naselja nastajala v bližini obstoječih prometnic, so se izoblikovale - čeprav večinoma ravno tako na črno - tudi pomožne prometne površine. Večji problem predstavljajo neurejene prometne površine znotraj naselbin. Zaradi vse gostejše zazidave postajajo pretesne, poleg tega pa jih deloma zasedejo tudi odlagališča sekundarnih surovin. Oddaljenost od javnih prometnih sredstev sedaj ne predstavlja velike ovire, saj so se navadili na prevoze z lastnimi prevoznimi sredstvi. Vozni park ni najbolje oskrbovan, še slabše pa je s prometnimi dovoljenji.

Velik problem predstavljajo zlasti komunalni odpadki. Na kanalizacijsko omrežje so priključena le redka romska naselja. Odplake so precejšen problem, saj obremenjujejo lokalno okolje in predstavljajo zdravstveno-sanitarno grožnjo najprej stanovalcem samim, prav tako 
pa tudi sosedstvu (to je pogost razlog lokalnih konfrontacij). Odvoz smeti je urejen za večino naselij in tako ne predstavlja več motečega dejavnika. Vendar se stopnjujejo problemi z neurejenim zbiranjem kovin in drugih sekundarnih surovin.

Preglednica 1: Opremljenost romskih naselij v Sloveniji z električno energijo in vodno oskrbo. Število naselij po območjih.

Table 1: The water supply and equipment with electrical energy of Roma-settlements in Slovenia. The number of settlements by the regions.

\begin{tabular}{|c|c|c|c|c|c|c|c|}
\hline \multirow[b]{2}{*}{ območje } & \multicolumn{3}{|c|}{ oskrba z vodo } & \multicolumn{3}{|c|}{$\begin{array}{c}\text { delež gospodinjstev z električno } \\
\text { napeljavo }\end{array}$} & \multirow[b]{2}{*}{$\begin{array}{c}\text { skupaj število } \\
\text { upoštevanih } \\
\text { naselij }\end{array}$} \\
\hline & $\begin{array}{c}\text { javni } \\
\text { vodovod }\end{array}$ & $\begin{array}{l}\text { lokalni } \\
\text { vodni viri }\end{array}$ & $\begin{array}{c}\text { brez } \\
\text { oskrbe } z \\
\text { vodo }\end{array}$ & $\begin{array}{l}\text { vsi ali } \\
\text { večina }\end{array}$ & $\begin{array}{c}\text { Delna } \\
\text { oskrba } \\
\text { z el. } \\
\text { energijo }\end{array}$ & $\begin{array}{c}\text { brez } \\
\text { električne } \\
\text { napeljave }\end{array}$ & \\
\hline Prekmurje & 19 & 16 & 3 & 23 & 15 & 0 & 38 \\
\hline Dolenjska* & 32 & 7 & 18 & 27 & 6 & 24 & 57 \\
\hline ostalo & 10 & 2 & 0 & 8 & 4 & 0 & 12 \\
\hline skupaj & 61 & 25 & 21 & 58 & 25 & 24 & 107 \\
\hline
\end{tabular}

$*_{z}$ Belo krajino, Kočevskim in Posavjem

Vir: -Anketa: Romska naselja v Sloveniji, Strokovna skupina za reševanje prostorske problematike romskih naselij v Sloveniji, MOP, februar-marec 2007, vse upravne enote RS, za vsako romsko naselbino posebej -Bivalne razmere Romov po občinah v Sloveniji, Urad RS za narodnosti, 2004-2005, interno gradivo

\section{FUNKCIJE ROMSKIH NASELIJ}

Vprašanje funkcij romskih naselij namenoma postavljamo v ospredje obravnave, ker se ta vidik skoraj kot po pravilu zanemarja. Pri tem izhajamo iz dveh domnev: prvič, da je vsaka naselbina dejansko večfunkcionalna in drugič, da skuša posameznik zaradi racionalizacije doseči glavnino svojih potreb v bližini. Iz opravljanja teh funkcij izhajajo tudi različni problemi, ki motijo tako njihove prebivalce kakor tudi vse tiste, ki so v dometu izbranega naselja. Te funkcije so: bivanje, izobraževanje, oskrba, delo, rekreacija in sprostitev, druženje, ohranjanje in razvoj kulture in identitete. Temu smo v omenjeni raziskavi posvetili pomembno pozornost. V nadaljevanju navajamo najprej funkcije, nato pa še nekatere izstopajoče probleme, ki jih je mogoče na splošno opaziti v zadnjih letih.

Bivanje predstavlja osnovno in izhodiščno vlogo. Romska naselja so sicer bivalne enote, vendar z mnogimi slabostmi, ki izvirajo iz lokacije, kakovosti gradenj in stanovanjske opreme. Te slabosti se odražajo predvsem navznoter, torej v škodo Romom samim, obenem pa jih ovirajo na drugih področjih (Zupančič, 2006, 66-67). Posebej jasno se je to izkazalo pri primeru naselja Smrekec pri Grosupljem. Lokacija v močvirju jim zaradi visoke talne vode, vlage, mrčesa in ostalih prilik povzroča več težav. Zaradi slabe komunalne opremljenosti je prisoten smrad; povzroča tudi nekatere zdravstvene probleme (Steklačič, 2003). 
Nobeno romsko naselje v Sloveniji nima na svojem ožjem (naselbinskem) teritoriju vzgojno-izobraževalne enote. Romi obiskujejo šole v sosedstvu. To jih po eni strani sili v oblikovanje stikov $\mathrm{z}$ ostalim prebivalstvom in s tem načeloma prispeva k njihovi družbeni integraciji (Tancer, 1999, 155-158), po drugi strani pa so ti bližnji stiki pogosto tudi točke konflikta. Pomanjkanje električnega in telefonskega omrežja ne omogoča uporabe sodobnih medijev, kar učence ovira pri doseganju boljšega učnega uspeha ter vzbuja (poleg mestoma še prisotnih negativnih stereotipov) ali poglablja občutke manjvrednosti. Oddaljenost je lahko pomemben dejavnik, saj so nekatera romska naselja oddaljena od šole in je posebej pozimi dostopnost šole slabša. Toliko bolj ugodne rezultate lahko opazimo pri vrtcih (na primer Pušča, Brezje), saj je precej povečala interes Romov pri skrbi za urejanje okolja.

Posebno mesto imajo romska naselja tudi na področju dela. Specifike romske ekonomije, naslonjene na različne vire dohodkov, je v več primerih pogojevala celo lokacijo teh naselij. Zaradi skromne zaposlenosti $\mathrm{v}$ industriji, storitvah, upravnih in drugih dejavnostih s formalno sklenjenimi delovnimi pogodbami so romska naselja $\mathrm{v}$ bistvu tudi pomembna prizorišča romske ekonomije neposredno ali pa so posredno povezana s tem. Ta vidik se pri analizi položaja Romov in predvsem v luči prostorsko-socialnih odnosov nekoliko zapostavlja, čeprav je ravno zaradi tega tako sporen v odnosih do okoliškega prebivalstva. Primanjkljaj kmetijsko proizvodnih površin in vrtov Romi ponekod kompenzirajo s posegi v sosednja kmetijska zemljišča, kar povzroča $\mathrm{v}$ prvi vrsti spore $\mathrm{z}$ okoliškim prebivalstvom. Med pomembne gospodarske dejavnosti Romov sodi tudi zbiranje, urejanje in preprodaja sekundarnih surovin, kot so papir, plastika, steklo in predvsem kovine. Zaradi teh aktivnosti, ki potrebujejo precej manipulativnega prostora, prihaja do občutne zasmetenosti naselja in njegove bližnje okolice, pojava zaprašenosti, smradu (zaradi sežiganja npr. gum, kablov in drugih izdelkov, iz katerih potem pridobijo dragocene surovine za preprodajo). Zlasti v manjših romskih naseljih, kjer prostora pač primanjkuje, je to zelo občuten notranji problem. Gosta pozidava onemogoča urejanje teh aktivnosti znotraj naselja, poleg tega pa je zaradi vplivov na okolje moteč tudi za same Rome. Zato nastajajo proizvodni in servisni otoki na robovih naselij, bližje prometnicam in s tem toliko bolj na očeh in v spotiko pri okoliškem prebivalstvu. V Grosupljem je ta problem dokaj prisoten in razlog že nekaj sporov.

Zelo podobno je pri oskrbi. Zelo redko so romske naselbine opremljene s katero izmed oskrbnih funkcij: trgovino, gostinskim lokalom, zdravstveno postajo, enoto pošte, banke in drugih sodobnih storitev. Romi jih zato iščejo v sosedstvu.

Edino rekreativne potrebe, druženje in zabavo najdejo Romi v okviru svojih naselbin, posebno če so te nekoliko večje. Vendar je to neredko v veliko nejevoljo okoliških prebivalcev, ki zaradi uzurpacije in motenja posesti trpijo določeno škodo. Del druženja in zabave se odvija tudi v ustreznih objektih v okolici. Medkrajevne in še posebej medregionalne razlike so tukaj zelo očitne. V Prekmurju Rome praviloma sprejemajo tudi kot glasbenike in so zato v regionalni folkloristiki prepoznaven, včasih celo iskan element. Na Dolenjskem je bila prisotnost Romov pri večjih prireditvah največkrat razlog za izgrede. Nedvomno igrajo pri tem veliko vlogo prisotni stereotipi in predsodki.

Družabno življenje ima poseben pomen za ohranjanje in razvoj romskega jezika in kulture in s tem tudi romske identitete. Položaj Romov je na tem področju poseben, neprimerljiv s katero koli drugo etnično skupino v slovenskem prostoru. Zgoščenost Romov v romskem 
naselju nedvomno pripomore $\mathrm{k}$ ohranjanju romskega jezika, medgeneracijskem prenosu romske kulture v najširšem smislu in s tem k ohranjanju njihove identitete, v sklopu katere ima tudi specifičen način življenja, vrednote in predstave očitno vidno vlogo. Toda obenem je to tudi dejavnik določene getoizacije, samozadostnosti in izogibanja stikov z ostalim prebivalstvom, še posebej otrokom in mladini. Tudi zaradi tega vstopajo v vzgojno-izobraževalni sistem preskromno pripravljeni z znanjem slovenskega jezika, kar ob zadrževanju družabnih stikov pretežno z Romi in pomanjkanju medijske oskrbe (ki je v tem pogledu tudi posrednik jezika) rezultira v slabšem znanju slovenskega jezika in s tem skromnejši konkurenčnosti Romov na trgu dela. Obenem pa vzgojnoizobraževalni sistem zaradi odsotnosti upoštevanja romščine kot pomembnega vira in elementa romske identitete (ter tudi upoštevanja njihove kulture) lete ne ohranja, vzpodbuja in razvija, temveč nasprotno, prispeva k nazadovanju teh elementov in s tem osebni razdvojenosti med »romskim« in »civilnim«, kar potem struktura, videz in funkcija romskih naselij samo še utrjujeta. Nedvomno bodo imele prihodnje raziskave na tem področju še veliko dela. Skoraj pa ne moremo dvomiti, da je tovrstni integracijski model v bistvu tudi asimilacijski.

Pregled funkcij romskih naselij lahko sklenemo z ugotovitvijo, da romska naselja zagotavljajo poleg bivalne (stanovanjske) le zelo omejeno mero ostalih vlog, ki se lahko nudijo na ravni naselja. Ta primanjkljaj ovira Rome na drugih področjih in zmanjšuje njihovo uspešnost pri različnih vidikih družbene integracije. Celo več: izvrševanje različnih funkcij na lokalni ravni vodi v konfrontacijo ali celo konflikte $\mathrm{z}$ okoliškim prebivalstvom. Pri urejanju in načrtovanju romskih naselij bo potrebno funkcijam nameniti večjo pozornost.

\section{PROBLEMI ROMSKIH NASELIJ}

\section{Problemi znotraj romskih naselij}

Zaradi svoje lokacije, izgleda, gradbene strukture, lastništva, arhitekturne in komunalne ureditve ter opremljenosti imajo Romi v svojih naseljih vrsto problemov. Bivalni problemi so namreč izhodišče tudi nekaterih drugih težav, posebej pri doseganju ustrezne stopnje izobrazbe, poklicnih kvalifikacij, dodatnih izobraževalnih možnosti, informiranosti, zdravstvenih in socialnih storitev, dostopa do delovnih mest in skratka dostopa do vključevanja v slovensko družbo na različnih področjih. Neredko so prav neustrezne bivalne razmere krive za poznejše neuspehe. Varnostna vprašanja se tako vpletajo v ostale nianse bivanja v romskih naseljih. Posebej omenjamo naslednje probleme:

- neprimerna lokacija (poleg vprašanja legalnosti mislimo tu predvsem na nefunkcionalnost nekaterih lokacij),

- neurejeno lastništvo (večinoma niso lastniki parcel oziroma zemljišč),

- $\quad$ odsotnost planskih aktov (nelegalnost!),

- $\quad$ stanovanjske enote $\mathrm{v}$ romskih naseljih pogosto niso oštevilčene; zaradi tega prihaja pri souporabi npr. vode, elektrike ipd. do sporov med uporabniki,

- $\quad$ prostorske omejitve širjenja naselja,

- $\quad$ zgoščevanje naseljevanja, ki presega minimalne standarde; spori med sosedi,

- $\quad$ praviloma slaba komunalna in infrastrukturna opremljenost; souporaba zahteva zelo dosledne gospodarske odnose med stanovalci-sosedi; neredko spori, 
- $\quad$ nizek stanovanjski standard večjega dela stanovanjskih objektov,

- pomanjkanje oziroma odsotnost arhitekturnih in krajinskih modelov romskih naselij,

- $\quad$ pomanjkanje prostora za nekatere oblike gospodarskih dejavnosti,

- $\quad$ povzročanje smradu, prašnosti, zasmetenost; je opazen zdravstveni in ne zgolj estetski problem,

- $\quad$ ogrožanje vodnih virov ter naravne in kulturne dediščine,

- $\quad$ resni notranji konflikti (pogosto sodijo med t.i. meddružinske spore in se lahko vlečejo tudi dalj časa).

Zaradi notranjih tj. medromskih sporov je bilo že kar nekaj selitev. S socialno stratifikacijo, še posebej če je ta pridobljena (tudi) z nelegalnimi aktivnostmi, se oblikujejo tudi struje, ki na lokalnih ravneh znotraj romskih skupnosti uveljavljajo tudi povsem svoja pravila. Tako se je tudi v nekaj novejših primerih (šlo je poizkuse uveljavljanja legalnih naselij z združevanjem romskih naselbin) izkazalo, da se določene skupine prenašajo slabo. Rezultat tega so tudi selitve in s tem nastajanje novih bivalnih enot, ki niso zgolj rezultat oblikovanja novih (mladih) družin. Mnoge naselbine so zaradi tega številčno dokaj stabilne, saj ne tolerirajo novih naselitev.

\section{POGOSTI PROBLEMI SOBIVANJA ROMOV IN OKOLIŠKEGA PREBIVALSTVA TER VPRAŠANJE VARNOSTI}

Historični viri in analize o odnosih med romskim prebivalstvom in bližnjim socialnim okoljem, s katerimi so prihajali v stik, je polno navedb, da je nenaklonjenost Romom skoraj permanentna. Integracije Romov so bile (tudi) v preteklosti neuspešne, tudi če so jih skušali uveljaviti s precej trdimi prijemi. Pozneje, zlasti pa po drugi svetovni vojni so se vsaj v Sloveniji uveljavili bolj permisivni koncepti, ki pa tudi niso dali želenih rezultatov. Celovitih integracijskih konceptov ni bilo, s stalno naselitvijo in še posebej nadaljnjimi koraki družbene modernizacije pa so se problemi na teritorialno-socialnem stiku Romov in lokalnega prebivalstva stopnjevali. Mnoge družboslovne / humanistične razprave so se v luči zavedanja v preteklosti Romom povsem nenaklonjenega okolja in seveda tudi politik pač zatekale $\mathrm{k}$ naivnemu pričakovanju, da bo mogoče $\mathrm{z}$ vrsto spodbujevalnih »mehkih« ukrepov preseči večgeneracijsko neneklonjenost do Romov. Vendar so stavili na napačnega konja - bolje rečeno, le-temu niso naklonili skoraj nobene sistemske podpore, temveč so lokalno prebivalstvo postavili v vlogo trpnega spremljevalca novih okoliščin. Romi so s stalno naselitvijo izgubili temelje stare »ekonomije«, okolišani pa postajali zaradi spremenjenih ekonomsko-socialnih odnosov bolj ranljivi. Le redke občine (stare, op. p.) so pristopale bolj sistematično in tudi dosegle boljše izide. Zato so se ob ohranjanju in celo stopnjevanju problemov na ravni bližnjega teritorialno-socialnega stika odnosi med Romi in okoliškim prebivalstvom pogosto zaostrovali. Družboslovno-humanistične analize pa so - po oceni pisca - zelo pogosto prezrle stopnjujoče se lokalne probleme oziroma jih razvrščale v kategorijo načelnega nasprotovanja in nenaklonjenosti Romov ter jih označevali za rasistična, nestrpna, nacionalistična, sovražna ipd. (Žnidarec Demšar S., 2006, 50-51) Jasno, da z ignoriranjem problemov in odsotnosti medativnih posegov, ki naj bi vzpostavljale novo (boljšo, sprejemljivejšo) raven odnosov 
v praksi ni bilo posluha. Naivno pričakovanje, da se morajo pač okolišani »navaditi« na kulturne in siceršnje specifike svojih novih romskih sosedov, so naletele ne le na gluha ušesa, temveč pomagale k gradnji barier, ki so jih oboji potem težko premagovali. Premalo je bilo tudi zavedanja, da utegne prav ignoriranje realnih problemov spodbuditi in utrjevati Romom nenaklonjeno držo lokalnega prebivalstva.

Ob stikih z Romi se ob izkazanih problemih, ki zadevajo slednje (glej zgoraj), čuti lokalno prebivalstvo zelo pogosto prizadeto. Dodatni problemi, ki skoraj po pravilu (so pa tudi izjeme!!) spremljajo občine z romskim prebivalstvom, predstavljajo ne le lokalni, temveč regionalni problem. V preteklosti se je že javilo več primerov, kjer je neprimerna lokacija in struktura romskega naselja izhodišče napetosti. V splošnem pa lahko glede na dosedanje proučevanje izpostavimo predvsem naslednje težave:

- $\quad$ uzurpacija zemljišč za lokacijo romskih naselij, odlaganje materialov in druge zasedbe parcel -motnje posesti, rabe zemljišč in gospodarskih dejavnosti,

- $\quad$ povzročanje neposredne škode zaradi kraje, nenamernega uničevanja,

- vizuelna devastacija zaradi odlaganja odpadkov, izgleda naselij in spremljajočih površin,

- $\quad$ povzročanje smradu, povečevanje prašnosti, onesnaževanje vodotokov ali podtalnice oziroma kraških vodnih zajetij,

- $\quad$ vožnje z neregistriranimi avtomobili in brez ustreznih zavarovanj; v primerih nesreč imajo udeleženci praviloma zelo skromen možnosti vračila stroškov,

- $\quad$ oviranje prometa zaradi nenamernega zbiranje sekundarnih surovin kot so zlasti kovine in steklo) ali namernega zasmetevanja prometnih površin,

- oviranje gospodarskih dejavnosti, predvsem kmetijstva in turizma,

- $\quad$ obstoj konfliktov, strah zlasti starejšega prebivalstva pred nasiljem ipd.

- razraščanja kriminala v nekaterih primerih prinaša nepomirljive odnose s sosedstvom.

Živimo v postmoderni, informacijski družbi. Uspeh posameznika in dvig na socialni lestvici je usodno odvisen od tehničnih možnosti komunikacije na eni ter strokovne usposobljenosti in znanja kot osnovne razvojne dobrine. Toda taka družba je obenem tudi veliko bolj ranljiva kot pa na primer prejšnja kmečka (agrarna) in tudi industrijska. Moteči dejavniki v bližnjem okolju ter na območjih, ki jih dosega posameznik pri opravljanju svojih funkcij, se zato hitro prepoznajo kot velike razvojne težave ter resno oviranje kakovosti življenja. V luči prostorsko-socialnih odnosov dobijo konfrontacije in nevšečnosti, ki jih Romi povzročajo svojim sosedom (zelo redko je obratno) povsem nove razsežnosti. Težje dosegajo ne le delovna mesta, temveč tudi različne oblike oskrbe, rekreacije, sprostitve, dodatnega (permanentnega) izobraževanja. Vsak vlom v stanovanjsko hišo pomeni tudi bistveno večjo škodo zaradi elektronskih naprav, shranjenih podatkov in drugih sodobnih dobrin in pridobitev. Vse to lahko stopnjuje negativno percepcijo Romov in utrjuje stare (v glavnem negativne) stereotipe o njih. Toda to so realni problemi in omalovaževanje teh težav le stopnjuje prepad med enimi in drugimi. Še toliko bolj so zaradi pomanjkanja sodobnih dobrin prikrajšani Romi. Slabe bivalne razmere, povezane z neugodno lokacijo in ureditvijo romskih naselbin so tako vztrajen bumerang, ki vselej zadeva najprej Rome, posledično pa tudi njihovo sosedstvo. 
Ponekod so postale resen problem tudi droge, bodisi njihovo razpečevanje ali pa uživanje, kar skupaj s problemi alkoholizma povzroča vrsto težav najprej znotraj romskih družin in romskih naselij, obenem pa hitro negativno vpliva na okolico povsod tam, kjer prihajajo $\mathrm{v}$ bližnje socialne stike. Ti pojavi imajo tudi sicer v slovenski družbi na splošno žal čedalje širše razsežnosti in jih je treba jemati nadvse resno kot spremljevalce sodobnega življenja, ne glede na kulturno ali etnično poreklo. Omenjamo pa jih, ker so vsaj v nekaterih primerih, ki jih je bilo mogoče ugotoviti, zelo velik problem.

$\mathrm{Ob}$ tem ne smemo zanemariti tudi ne tako redkega zlasti verbalnega nasilja, ki so ga deležni Romi ali pa ga - tudi zaradi lastnih stereotipov in pogosto nizki samopodobi - gojijo tudi oni sami. Ker se to primarno navezuje na možnosti zaposlovanja in s tem socialnega vzpona, ima to zapostavljanje vrsto negativnih posledic.

Posebej je treba omeniti, da so Romi pogosto $» k r i v i \ll$ za prestopke, ki se jim jih pripisuje, ne da bi jih storili oziroma dokazali. Ker pa zaradi pogosto očitane premajhne pozornosti in učinkovitosti varnostnih sil in sodnega sistema mnogih prestopkov in sorazmerno resnih težav oškodovanci mnogokrat niti ne prijavljajo (pogosta navedba, da se to ne izplača in so potem le še bolj tarča nasilja), je tu široko sivo polje uradno »neznanega in neobstoječega«, toda za lokalno, prizadeto prebivalstvo nadvse moteče, pa tudi gospodarsko ogrožujoče. Po drugi strani pa obstoj tega sivega polja vzbuja, stopnjuje in razširja apriorne negativne stereotipe o Romih med okoliškim prebivalstvom, zmanjšuje možnosti dialoga in povečuje možnosti konfrontacije, ki se lahko hitro (kot smo bili v preteklih mesecih in letih že priče) prevesijo v lokalne konflikte $\mathrm{z}$ nepredvidljivimi in lahko usodnimi posledicami. Zavedati se je treba, da je reševanje tudi majhnih konfliktov in vzpostavljanje možnosti dialoga potem izredno težavno, drago in uspeh negotov. Konfrontacije in konflikti Romom v splošnem ne prinašajo dobrega. Po izkušnjah sodeč jih hitro doletijo posplošene negativne sodbe in utrjujejo psihološke pregraje o (ne)možnostih sobivanja. Prav zaradi tega je pozornost tudi do navidezno malih problemov dolgoročno pomembnejša, kot se zdi na prvi pogled. Omalovaževanje teh problemov pri oškodovanem prebivalstvu oziroma povsod tam, kjer se je zaradi realnih težav v preteklosti razvili občutki (ali izkušnja!) ogroženosti ovira ali celo preprečuje, da bi lokalno prebivalstvo razumelo in lažje sprejelo različne ukrepe, ki vodijo k legalnosti bivanja kot enem od najpomembnejših izhodiščnih pogojev družbene integracije in privzema, predvsem pa tudi doseganja življenjskega standarda kot ga ima ostalo prebivalstvo. Prav v tem je treba videti specifiko varnostnega vprašanja $\mathrm{v}$ kontekstu urejanja prostorskih razmer $\mathrm{v}$ romskih naseljih.

Posebno poglavje $\mathrm{v}$ kontekstu varnostnih vprašanj $\mathrm{v}$ romskih naseljih so tudi odnosi Romov do oseb, ki opravljajo različne službe (socialni delavci, zdravstveno osebje, učitelji in vzgojitelji, policisti, predstavniki občin, zastopniki humanitarnih organizacij in podobni poklicni profili, ki se po svoji dolžnosti srečujejo z Romi oziroma so zadolženi za izvajanje določenih opravil). Dosedanje izkušnje, ki smo jih zaznali tudi v delu strokovne skupine (tovrstnih navedb in izkušenj je tudi sicer veliko), vodijo k nezanemarljivemu področju, ki se je doslej razmeroma redko omenjalo. Nekateri doživljajo ob svojem delu oziroma zaradi njega grožnje, celo najhujše. Predvsem je to pogosto v primerih, ko so po svojih poklicnih pristojnostih in dolžnostih zavrniti želje, interese ipd. nekaterih Romov. $V$ to skupino se lahko uvrstijo tudi romski svetniki, ki se v komunikaciji s predstavniki lokalnih oblasti (občinski svet, občinska uprava, javnost) znajdejo v koliziji interesov z nekaterimi skupinami Romov v 
»svoji« občini. Ne nazadnje je zlasti v občinah z več romskimi naselji, ki so neredko nastala prav zaradi nesoglasij med posameznimi skupinami Romov. Glede na dokaj pozitivne izkušnje inštituta romskega svetnika kot predstavnika in zastopnika interesov Romov, obenem pa tudi osebe, ki mora po svoji poziciji utrjevati poti sporazumevanja in dialoga z lokalno skupnostjo, se zlahka znajdejo soočeni ne le z grožnjami, temveč tudi poskusi resnih obračunov (Poročilo o delu Strokovne skupine za reševanje prostorske problematike romskih naselij, 2007)

\section{POGOJI NAČRTOVALSKIH POSEGOV V ROMSKIH NASELJIH}

Med pričakovanji, ki jih Romi pogosto naslavljajo na lokalno in tudi državno raven prostorskega načrtovanja, so tudi t.i. »legalizacije« romskih naselij. Kot je bilo že omenjeno, so romska naselja z legalističnega vidika večidel črne gradnje, ki potem predstavlja

izhodišče začaranega kroga: ker ni ustreznih dokumentov in načrtovalskih opredelitev, niso deležni strukturnih pomoči in vlaganj npr. v infrastrukturo. Pomanjkanje le-te pa jim dalje ne nudi primernih možnosti ne za šolanje otrok in ne za konkurenco na trgu delovne sile. Zaradi brezposelnosti ne dosegajo ekonomskega praga vključenosti v družbo in izboljševanje lastnega življenjskega standarda. In krog je tako sklenjen.

Preglednica 2: Delež črnih gradenj v romskih naseljih po območjih Slovenije. Število naselij.

Table 2: The share of illegal constructions in Roma settlements in Slovenia by the regions. The number of settlements.

\begin{tabular}{|l|r|r|r|r|r|r|}
\hline območje & \multicolumn{1}{|c|}{$\begin{array}{c}\text { vse so črne } \\
\text { gradnje }\end{array}$} & \multicolumn{1}{c|}{$\begin{array}{c}\text { večina } \\
\text { so črne } \\
\text { gradnje }\end{array}$} & $\begin{array}{c}\text { del } \\
\text { objektov } \\
\text { so črne } \\
\text { gradnje }\end{array}$ & $\begin{array}{c}\text { črnih } \\
\text { gradenj je } \\
\text { malo ali nič }\end{array}$ & $\begin{array}{c}\text { ni } \\
\text { podatkov }\end{array}$ & \multicolumn{1}{c|}{$\begin{array}{c}\text { Skupaj } \\
\text { romskih } \\
\text { naselij }\end{array}$} \\
\hline Prekmurje & 3 & 12 & 16 & 4 & 4 & 38 \\
\hline Dolenjska* & 39 & 6 & 7 & 4 & 0 & 57 \\
\hline ostalo & 1 & 2 & 0 & 1 & 8 & 12 \\
\hline skupaj & 43 & 20 & 23 & 17 & 12 & 107 \\
\hline
\end{tabular}

* Belo krajino, Kočevskim in Posavjem

Vir: -Anketa: Romska naselja v Sloveniji, Strokovna skupina za reševanje prostorske problematike romskih naselij v Sloveniji, MOP, februar-marec 2007, vse upravne enote RS, za vsako romsko naselbino posebej

Črne gradnje so v romskih naseljih odločno v prevladi, ne glede na območje. Vendar je na Dolenjskem večina romskih naselij takih, kjer so vsi objekti postavljeni nelegalno. Nedvomno je to slabo izhodišče za urejanje bivalnih razmer, še posebej če upoštevamo tudi že omenjene slabosti infrastrukturne opremljenosti. Vendar je »legalizacija« postopek, ki sam po sebi ne prinese funkcionalnih sprememb (kar se je izkazalo pri tovrstnih poskusih leta 1993, ko so na podlagi posebnega zakona in sledečih uredb skušali izboljšati stanje na tem področju. Zakon je dosegel le manjši del objektov in območij, potrebnih tovrstne sanacije, navrgel pa je več problemov. Zaradi pomanjkanja prostora na tem mestu ne moremo razpravljati.). Poleg tega sta za učinkovito reševanje problemov $\mathrm{v}$ romskih naseljih pomembna - poleg sprememb $\mathrm{v}$ 
strukturi in funkciji samih bivališč oziroma naselij v celoti - vsaj še dva elementa. Območje romskih naselij je potrebno opredeliti (skladno s področno zakonodajo) kot zazidalno in jim torej spremeniti namembnost. Drugi pogoj pa je urejeno lastništvo zemljišč, predvidenih za stanovanjsko (in drugo) gradnjo.

Preglednica 3: Romska naselja v Sloveniji glede na plansko opredeljenost. Število naselij.

Table 3: The Roma settlements in Slovenia by the status of planning. The number of settlements

\begin{tabular}{|l|c|c|c|c|c|}
\hline območje & $\begin{array}{c}\text { prostorska } \\
\text { dokumentacija } \\
\text { je urejena }\end{array}$ & $\begin{array}{c}\text { prostorska } \\
\text { dokumentacija } \\
\text { je načrtovana }\end{array}$ & $\begin{array}{c}\text { območje r.n. je } \\
\text { zunaj zazidalnih } \\
\text { območij }\end{array}$ & $\begin{array}{c}\text { neznano, } \\
\text { ni } \\
\text { podatkov }\end{array}$ & $\begin{array}{c}\text { skupaj } \\
\text { romskih } \\
\text { naselij }\end{array}$ \\
\hline Prekmurje & 22 & 6 & 5 & 5 & 38 \\
\hline Dolenjska* & 26 & 4 & 27 & 0 & 57 \\
\hline ostalo & 3 & 0 & 0 & 9 & 12 \\
\hline skupaj & 51 & 10 & 32 & 14 & 107 \\
\hline
\end{tabular}

$*_{z}$ Belo krajino, Kočevskim in Posavjem

Vir: Anketa: Romska naselja v Sloveniji, Strokovna skupina za rě̌evanje prostorske problematike romskih naselij v Sloveniji, MOP, februar-marec 2007, vse upravne enote RS, za vsako romsko naselbino posebej

V postopkih vzpostavljanja pravno legitimnih stanj je zelo pomemben in nujen korak tudi ureditev lastništva. To praviloma pomeni, naj bi stanovalci (Romi) pridobili lastništvo nad zemljiščem, kjer stojijo bivalni in drugi objekti (Preglednica 4). Uzurpacija zemljišč je pogost razlog konfrontacij in konfliktov, saj so lastniki (večidel kmetje, lokalno prebivalstvo) soočeni z znatno gospodarsko škodo.

Preglednica 4: Lastništvo zemljišč, na katerih stojijo bivalni in drugi objekti Romov v romskih naseljih

Table 4: The ownership of grounds, where different objects of Roma settlements are located. The number of settlements.

\begin{tabular}{|l|c|c|c|c|c|c|}
\hline območje & $\begin{array}{c}\text { lastniki } \\
\text { zemljišč so } \\
\text { večinoma } \\
\text { Romi }\end{array}$ & $\begin{array}{c}\text { Romi so } \\
\text { lastniki le } \\
\text { nekaterih } \\
\text { parcel }\end{array}$ & $\begin{array}{c}\text { zemljišče } \\
\text { je v lastni } \\
\text { občin in/ } \\
\text { ali države }\end{array}$ & $\begin{array}{c}\text { lastniki zemljišč } \\
\text { so drugi } \\
\text { (predvsem } \\
\text { zasebniki) }\end{array}$ & $\begin{array}{c}\text { neznano, } \\
\text { ni } \\
\text { podatkov }\end{array}$ & $\begin{array}{c}\text { skupaj } \\
\text { romskih } \\
\text { naselij }\end{array}$ \\
\hline Prekmurje & 18 & 1 & 6 & 2 & 10 & 38 \\
\hline Dolenjska* & 5 & 13 & 14 & 25 & 0 & 57 \\
\hline ostalo & 4 & 0 & 2 & 0 & 4 & 12 \\
\hline skupaj & 27 & 14 & 22 & 27 & 14 & 107 \\
\hline
\end{tabular}

\section{$*_{z}$ Belo krajino, Kočevskim in Posavjem}

Vir: -Anketa: Romska naselja v Sloveniji, Strokovna skupina za reševanje prostorske problematike romskih naselij v Sloveniji, MOP, februar-marec 2007, vse upravne enote RS, za vsako romsko naselbino posebej -Bivalne razmere Romov po občinah v Sloveniji, Urad RS za narodnosti, 2004-2005, interno gradivo 
Razlike med območjema - regijama - je treba opazovati predvsem v luči socialnih procesov in trajanja prostorske ustalitve. Ker so romska naselja v Prekmurju v povprečju starejša za vsaj desetletje ali dve (to je ena generacija), se to pozna tudi pri vzpostavljanju lastništva. Na Dolenjskem so bili Romi posestno manj uspešni. Le na videz je večje število zemljišč v lasti občin ali državnih institucij (predvsem slovenske vojske) lahko prednost pri urejanju lastništva (manj lastnikov - enostavnejši postopki). Občine se namreč pogosto odločajo za prodajo zemljišč po najvišjih cenah, kar pa pri romskih naselbinah ne morejo pričakovati. Vrh vsega je pogosto prisotna izkušnja, da bližina romskih naselij ne vpliva k zviševanju cen zemljišč (kar je v interesu lastnikov), temveč obratno k zniževanju in omejevanju možnosti. Za to imajo nedvomno »zasluge« tudi Romi kot stanovalci. Zaradi že omenjenih učinkov na prostor jih okoliško prebivalstvo pogosto dojema kot oviralni dejavnik pri njihovih gospodarskih ambicijah ter s tem utrjuje že tako prisotne stereotipe. Prav zaradi tega je ob nepripravljenosti lastnikov, da bi že zasedena območja po določenih (v anketi pogosto poudarjajo: tržnih cenah) prodali Romom zemljišča, težko predvideti kratkoročne rešitve.

\section{H KONCEPTOM REŠEVANJA PROSTORSKE PROBLEMATIKE ROMSKIH NASELIJ: POSKUS OPERACIONALIZACIJE}

Čeprav reševanje prostorske problematike romskih naselij ne pomeni nujno že tudi avtomatičnega izboljšanja položaja Romov, niti ne odpravlja latentnih napetosti in celo konfliktov, pa dolgoročno vendarle pripravlja okvire reševanja. V luči priprave krovnega zakona o romski skupnosti ob normativni naravnanosti ne moremo pričakovati neposrednega izboljševanje učinka. Šele operacionalizacija zakona, podkrepljena z ustreznimi programskimi in projektnimi okviri lahko pomeni pot neposrednega reševanja prostorskih problemov romskih naselij. Delovno izhodišče mora biti odpravljanje realnih problemov, ki jih imajo eni in drugi zaradi različnih življenjskih stilov v neposrednem stiku. Problem romskih naselij je treba opredeliti kot problem konfliktne rabe prostora - in to zaradi različnih razlogov večinoma tudi je.

Analiza stanja romskih naselij hitro pokaže ključne (prej naštete) probleme. Dosledno spoštovanje zakonodaje in predpisov s področja urejanja prostora in varstva okolja (ki jih tu zaradi pomanjkanja prostora ne navajamo) torej samo po sebi ne more reševati problemov. Zaradi zavarovanja različnih okoljskih prvin, preprečevanja škode, zmanjševanja konfliktnosti in omogočanja realnih možnosti boljše družbene integracije Romov bi bilo smiselno pristopiti k začasnim akcijskim rešitvam. Te bi morale predvidevati tudi trajnejše rešitve oziroma biti podlaga zanje. Nakazujejo se naslednje možnosti urejanja romskih naselij:

- $\quad$ integracija romskih naselij v obstoječi naselbinski sistem (kot del naselja),

- $\quad$ sanacija in vzpostavljanje legitimnih pravnoposestnih stanj romskih naselij,

- $\quad$ začasne (omejene!) prilagoditve romskih naselij

- $\quad$ sprememba lokacije, »prelokacija« (selitev),

- $\quad$ odškodnine lokalnemu prebivalstvu (Zupančič, 2006,17-18). 
Slika 1: Načrt ureditve romskega naselja Kerinov grm v občini Krško

Figure 1: The reconstruction-plan of Roma settlement Kerinov grm in Krško community

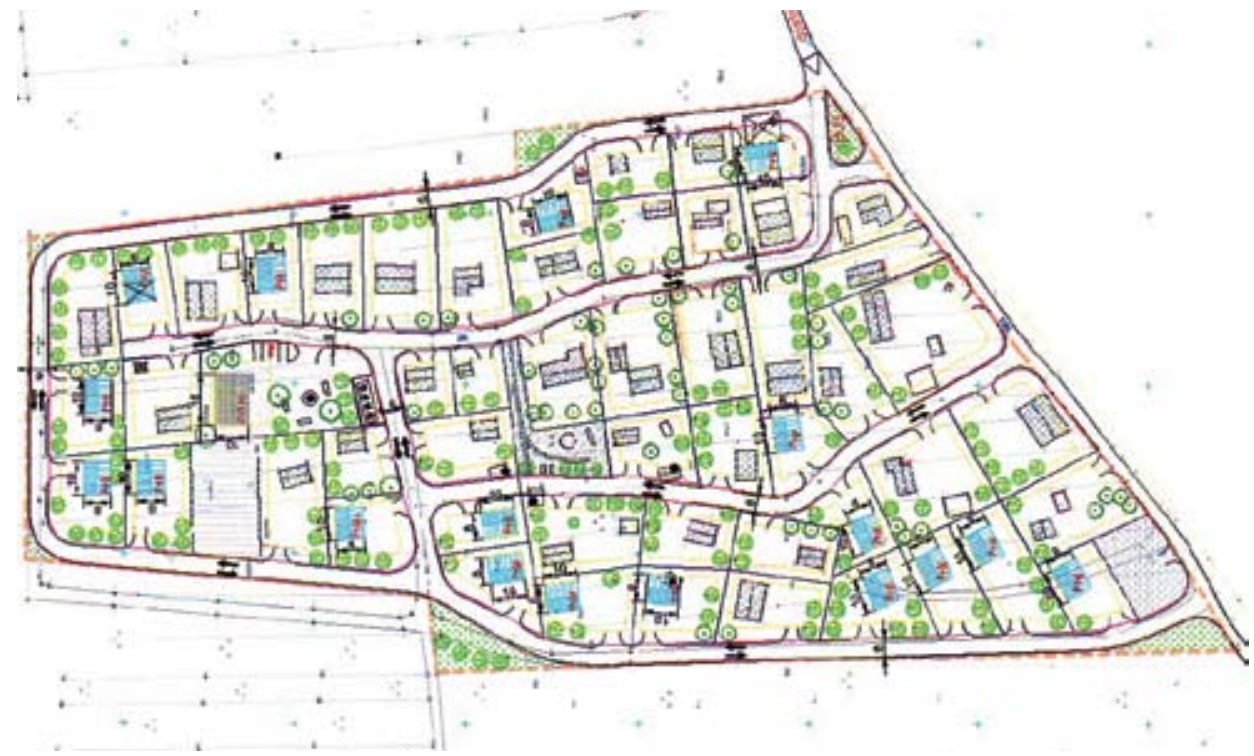

Vir: Romsko naselje Kerinov Grm, 2006, Krško

Že v začetku je treba opozoriti, da idealne lokacije romskih naselij ni; nastala so preveč stihijsko in se kasneje tako tudi širila ter spreminjala. Poleg splošnih pogojev, ki veljajo za vse posege v prostor, kot so na primer urejeno lastništvo, možnosti širitve, da ne ogrožajo vitalnih naravnih virov in tudi ne pomembne kulturne dediščine, da so prometno dostopne ipd.) je treba v primeru romskih naselij izpostaviti še nekatere specifične pogoje. Da bi Romi lahko dosegli čim uspešnejšo vključitev v družbo, potrebujejo vrsto specializiranih ustanov, ki so jim zmožna ponuditi strokovno pomoč. Gre predvsem za dostopnost do ustreznih izobraževalnih ustanov, zdravstvenih služb, centrov za socialno delo, poklicno usposabljanje in izobraževanje (tudi odraslih!). Posebej v zadnjih letih se je pokazal tudi izjemen pomen varnostnega segmenta in preventivnega dela policije. Bližina teh služb in za to kvalificiranih oseb je bistveno pripomogla k uspešnejši integraciji in zmanjševanju konfliktov, ne more pa jih povsem odpraviti.

O integraciji romskih naselij govorimo predvsem v primerih, ko so le-ta locirana $\mathrm{v}$ neposredni bližini ostalih naselij ali del njih. V tem primeru je ob prej omenjenih pogojih potrebno preveriti, ali obstajajo pogoji legalizacije stavbnega fonda in ostalih površin ter $\mathrm{s}$ tem odprte poti za vključitev v naselje pod splošnimi pogoji, kot je to določeno s področno zakonodajo. Vendar je teh primerov sorazmerno malo; večina romskih naselij je prostorsko ločenih od siceršnje naselbinske mreže. Zato je treba pretehtati možnosti druge opisane opcije: vzpostavitve legalnih stanj. Čeprav se zdi v luči urejanja prostorskih problemov ta ukrep privlačen, pa bi prehitre in premalo strokovno utemeljene »legalizacije« kasneje povzročale 
Slika 2: Posnetek enega največjih kompleksov romskih naselij v Sloveniji: Brezje in Žabjak pri Novem mestu. Z rdečo je obkroženo območje naselja Brezij, predvideno za vzpostavljanje legalnosti in komunalno ureditev

Figure 2: The figure shows one of the largest Roma settlements in Slovenia: Brezje and Žabjak near Novo mesto (Dolenjsko region). The area marked with red is the part of settlement of Brezje, plannned for communal reconstruction

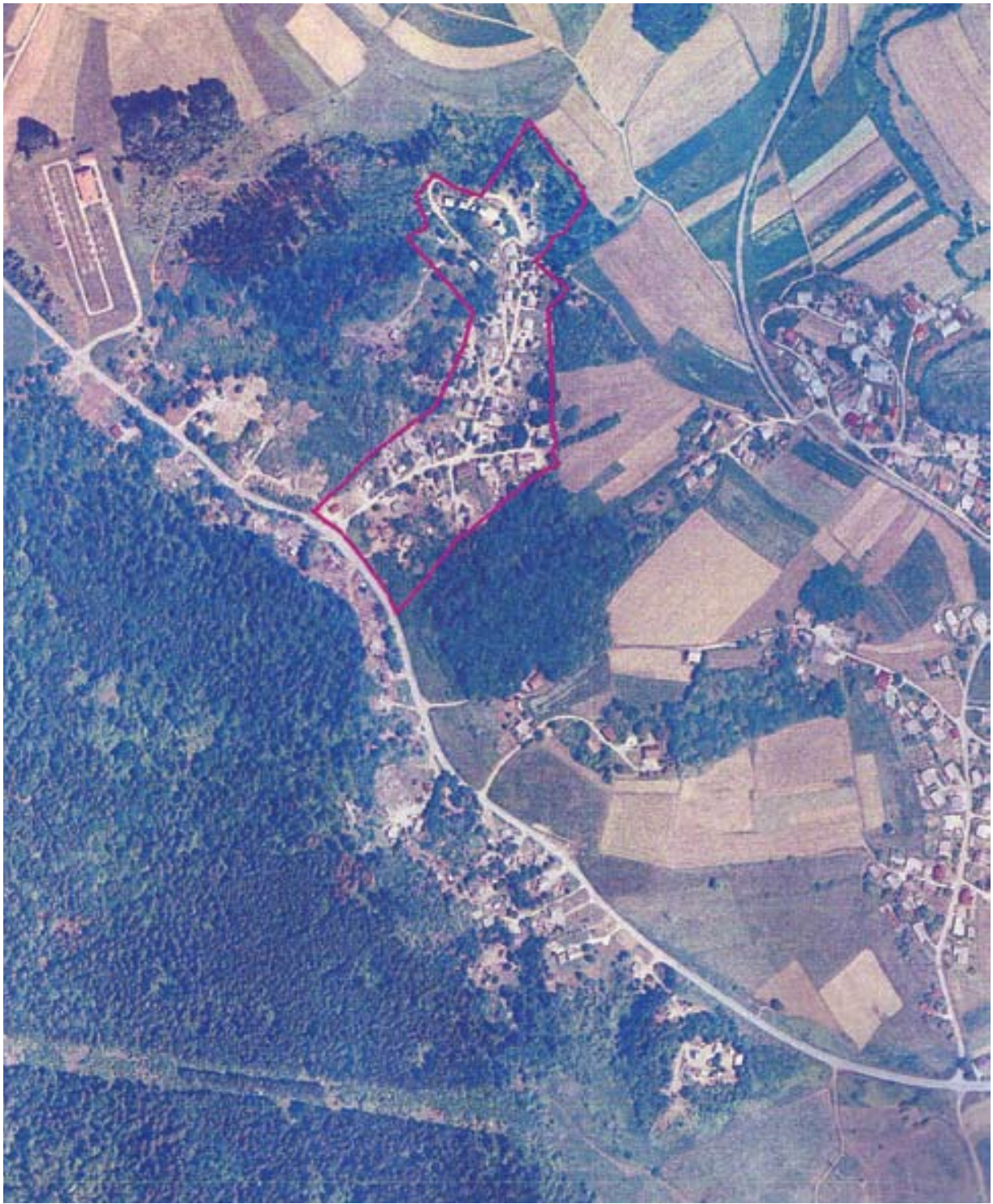

Vir: Romska naselja v Mestni občini Novo mesto, Acer, 2006, Novo mesto 
Slika 3: Romski naselji Brezje in Žabjak pri Novem mestu z vrisano parcelacijo. Naselji tvorita zaokrožen kompleks, vendar se statusno precej razlikujeta

Figure 3. The Roma settlements Brezje and Žabjak near Novo mesto, with drawed parcelation. Both settlements build common settlement- complex, but they differs by status of planning

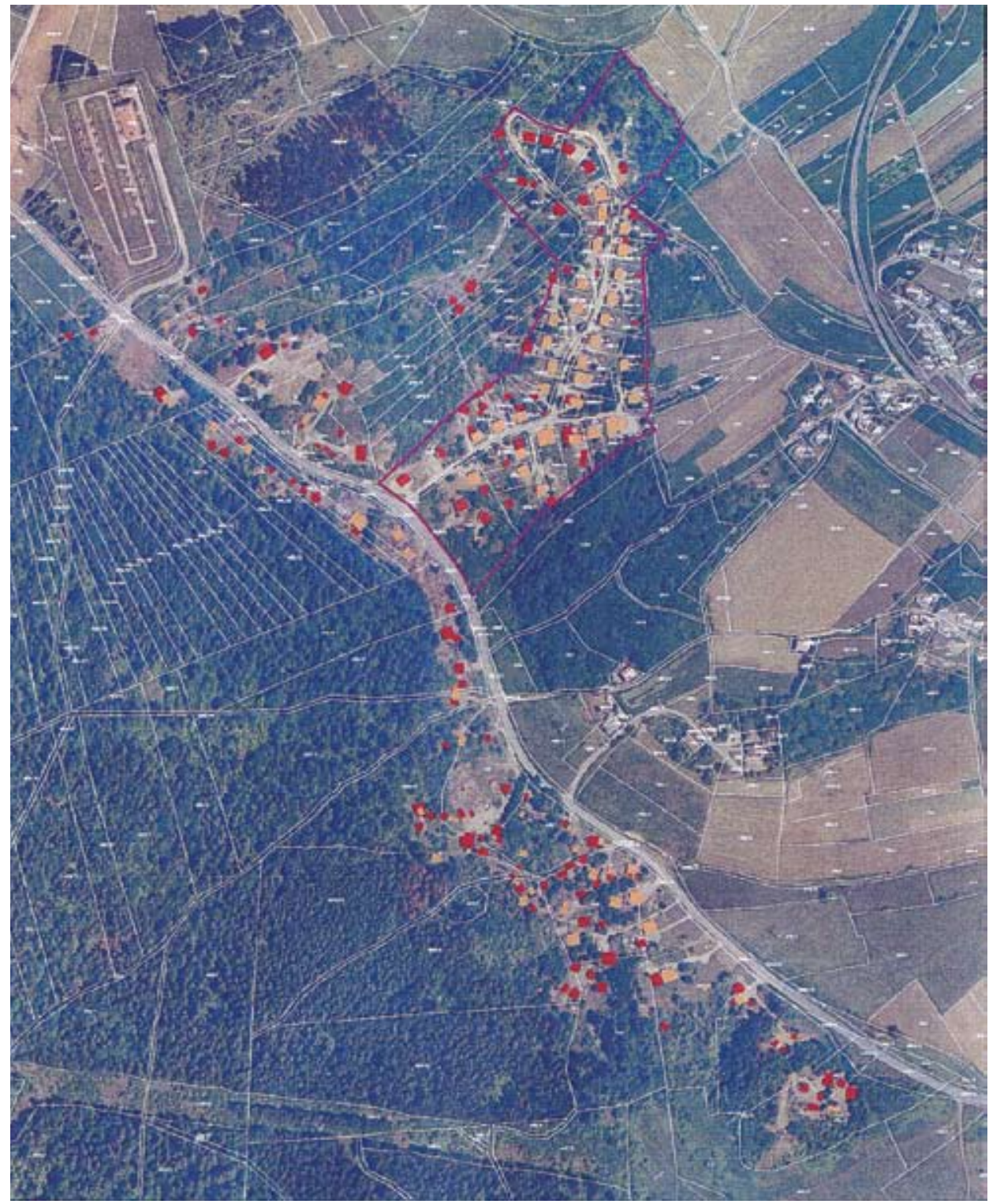

Vir: Romska naselja v Mestni občini Novo mesto, Acer, 2006, Novo mesto 
vrsto problemov. Ta postopek bi moral biti sorazmerno redko odstopanje od zakonsko opredeljenih norm in samo tam, kjer bi neizpodbitno ugotovili dolgoročno sprejemljivost takih lokacij. Veliko pogosteje se bo treba soočiti z možnostmi začasnih funkcionalnih prilagoditev v obstoječih »divjih« romskih naseljih. Teh ne bi legalizirali, akcijsko pa je morda dobro razmisliti o funkcijski in strukturni prilagoditvi. Ta možnost se ponuja kot oblika začasnega reševanja problemov in jih je mogoče izvajati v okviru projektov in programov. Pri tem bi morali jasno izpostaviti začasnost takih rešitev ter jih ciljno operacionalizirati. Cilj bi moral biti boljši pogoji za bivanje in posledično tudi izobraževanje, za delovno usposabljanje, zaposljivost in tako dalje. Voditi bi moral ven iz začaranega kroga.

Osnovno izhodišče urejanja romskih naselij naj bi bile obstoječe lokacije, če le ne ogrožajo pomembnih naravnih virov, kulturne dediščine in večjih gospodarskih načrtov (prometnice večjega pomena, velike gospodarske cone ipd.). Prav pri tem pa se v praksi na nekaj primerih že resno zapleta. Ker so leži precej romskih naselij na robu ali blizu lokalnih središč, ki so praviloma dovolj privlačne prav za nove raznovrstne strukturne objekte, so tako sicer za Rome ugodne lokacije nenadoma postale tvegane. Primeri Kočevja, Grosuplja, Novega mesta, Škocjana, Ribnice in tudi Ljubljane izpostavljajo ta problem zelo jasno, nadomestnih lokacij pa ni enostavno najti. Zlasti male občine so pri tem dokaj nemočne, saj ne razpolagajo ne s kapitalom in ne s primernim prostorom.

\section{I4. PRELOKACIJA (SELITEV) ROMSKIH NASELIJ - NESPREJEMLJIVA MOŽNOST?}

Če bi bilo nadaljnje vztrajanje romskega naselja na neprimerni lokaciji (ker ogroža pomembne življenjske vire, razvoj infrastrukture in druge, po strokovni presoji pomembnejše posege v prostor) je smiselno razmisliti o možnostih prelokacije naselja. To velja za vse primere, ne glede na kulturno ali etnično poreklo prebivalcev. Prav tako se ta rešitev ponuja v primerih, ko je nesporno mogoče ugotoviti, da na danih lokacijah adaptacije niso mogoče in dolgoročno legalizacije ne pridejo v poštev, ter tam, kjer ni pogojev za izvajanje projektov in programov, ki naj bi vodili k različnim oblikam družbene integracije Romov ter s tem dolgoročno izboljševanje njihovega stvarnega položaja. Prelokacija mora biti izvedena skladno z zakonskimi opredelitvami, to je z iskanjem nadomestnih možnosti in / ali ustreznih odškodnin ter zagotovitvijo o možnostih dolgoročne legalizacije novega naselja. Ukrep mora biti izveden sporazumno. Prav tukaj se zlasti manjšim občinam, ki upravljajo relativno zelo omejen prostor, možnosti teh ukrepov povsem ustavijo. Srečamo se s problemom nepriljubljenosti Romov in bojazni ali celo strahu lokalnega prebivalstva po poslabšanju ne le vizuelnih in funkcijskih okolja, temveč tudi zaradi morebitnega poslabšanja varnostnih razmer. Posebno poglavje predstavlja ureditev odnosov z lastniki zemljišč, kjer zaradi uzurpacije, motenja posesti ter zmanjševanja vrednosti zemljišč ter drugih težav. Kot smo že v uvodu omenili, je lokaliziranost romskega »problema« pogosto kriva tudi za nemoč lokalnih oblasti, če pri tem odmislimo tudi morebitne grožnje (ki menda niso ravno redkost) Romov do predstavnikov lokalnih oblasti, inšpekcijskih služb ali celo varnostnih organov. Če postavimo problem na državno raven, je morda pri iskanju nadomestnih, ugodnejših lokacij (na primer z javnim 
razpisom) vsaj načeloma več. Vsekakor pa sodijo prelokacije neustreznih (tudi romskih) naselij v povsem relevantne, čeprav zelo težavne in drage ukrepe (Zupančič, 2006, 625).

\section{ZAKLJUČEK}

Romska naselja so specifičen pojav $\mathrm{v}$ okviru slovenskega naselbinskega sistema. Stihijska po nastanku, razpršeno razmeščena $v$ panonski in subpanonski Sloveniji dajejo zanimiv izziv. Ali sploh potrebujemo ločena romska naselja? Na izzivalno vprašanje bi radi v duhu hitre družbene integracije odgovorili z odločnim NE. Ločena romska naselja, ki izstopajo predvsem po svojih notranjih in zunanjih problemih, ki obenem nimajo statusa »statističnih« naselij, ki so povečini nastala povsem ilegalno na tujih (uzurpiranih) zemljiščih, so videti v luči uveljavljanja splošnega urbanega reda tudi v podeželskih območjih predvsem neželeni element. Romom ne prinašajo ustreznega standarda in s tem izhodiščnih možnosti za uspeh v izobraževalni shemi ter dalje na trgu delovne sile, obenem pa so moteča za prebivalce sosednjih območij. Toda zavračanje Romov tudi s strani večinskega prebivalstva, da bi živeli v bližnjem sosedstvu, kakor tudi interesi romske populacije, ki se zaradi objektivnih (gospodarskih, socialnih) in subjektivnih (način življenja) razlogov raje držijo (če sploh lahko govorimo o možnostih izbire) posebnih romskih naselij (ali naselbin), navaja k misli, da je treba še naprej povsem resno računati na srednjeročni pojav posebnih romskih naselij. Čeprav reševanje zasilnih (in tudi izsiljenih) rešitev ni optimalna za nobeno stran, je v tem trenutku verjetno edina možna. Urejanje le teh je potrebno, če hočemo z ostalimi projekti družbene integracije uspevati korak za korakom. Hitre rešitve v smislu arbitrarne legalizacije in posledično tudi komunalne ureditve pa bi bil zopet tvegan korak, narejen bolj zaradi dokazovanja kratkoročne učinkovitosti in demonstracije Romom prijaznih politik. Neupoštevanje vidikov ogroženosti okoliškega prebivalstva Rome ne bo moglo razrešiti njihove apriorne stigmatizacije, temveč jih utegne $\mathrm{v}$ zaostrenih pogojih konkurenčnosti in iskanja lokalnih /regionalnih proizvodov (zlasti na področju npr. turizma) ob iskanju endogenih potencialov vztrajno potiskati stran od partnerstva $\mathrm{z}$ družbenim okoljem. Zaščitništvo mora biti torej dobro premišljeno in funkcionalno naravnano. S tem mislimo na večjo odgovornost tudi Romov za izboljšanje lastnega položaja, z vizijo, da so različne oblike pomoči zgolj prehodne. To nalaga tudi organizaciji romskih skupnosti na lokalni ravni nove naloge, državi pa bi morala narekovati tudi večjo pozornost upoštevanju in spoštovanju dobrin, ki so lastne vsakemu narodu in manjšim etničnim skupnostim: kulturi in jeziku ter varovanju identitete.

Prostorsko načrtovanje in urejanje romskih naselij se geografom odpira kot tema ki ji bo treba posvetiti veliko več pozornosti kot doslej. Geografija se je doslej temu posvečala odločno premalo. Toda prav kompleksen pristop $\mathrm{k}$ analizi pojavnih oblik in ustroja romskih naselij izzivata k nadaljnjemu poglabljanju in obširnemu empiričnemu raziskovanju. Prispevek naj bi spodbudil kritično razpravo in postopoma prispeval $\mathrm{k}$ jasnejši analizi in odločnejši sintezi. Do aplikacije, ki bi jih morali geografi nekoliko pogumneje zagovarjati in tudi izvajati, je potem le še korak. 


\section{Literatura}

Bivalne razmere Romov po občinah v Sloveniji, 2004-2005. Urad RS za narodnosti, interno gradivo

Horvat J., 1999. Položaj Romov v Sloveniji, Poti za izboljšanje Romov v Srednji in Vzhodni Evropi. Izziv za manjšinsko pravo, INV in OOSI, Izpostava Ljubljana, Ljubljana (ur. Klopčič V. in Polzer M.)

Jezernik B. (ur.), 2006. Zakaj pri nas žive Cigani in ne Romi?, Župančičeva knjižnica, 17, Ljubljana

Klien R., 1999. Posebni sistemi v politiki delovne sile za Rome, Poti izboljšanja položaja Romov v Srednji in Vzhodni Evropi, Izziv za manjšinsko pravo, INV in OOSI, Izpostava Ljubljana, Ljubljana, 106-112

Klopčič V., 1991. Pravni položaj Romov, Razprave in gradivo 25, INV, Ljubljana

Klopčič V., 1999. Pravni položaj Romov v mednarodnih dokumentih, Poti za izboljšanje Romov v Srednji in Vzhodni Evropi. Izziv za manjšinsko pravo, INV in OOSI, Izpostava Ljubljana, Ljubljana (ur. Klopčič V. in Polzer M.)

Komac M., Zupančič J., Winkler P., 1999. Varstvo narodnih skupnosti v Republiki Sloveniji, INV, Ljubljana

Poročilo o delu Strokovne skupine za reševanje prostorske problematike romskih naselij, 2007, elaborat, Ljubljana (ur. J. Zupančič)

Romska naselja v Mestni občini Novo mesto, elaborat, Acer, september 2006, Novo mesto

Romsko naselje Kerinov grm, 2006, elaborat, Občina Krško

Smerdu F., 1999. Predstavitev projekta »Problematika zaposlovanja Romov v občini Novo mesto, Poti za izboljšanje Romov v Srednji in Vzhodni Evropi. Izziv za manjšinsko pravo, INV in OOSI, Izpostava Ljubljana, Ljubljana (ur. Klopčič V. in Polzer M.)

Srienz- Polzer M., 1999. Primerjava pravnega položaja Romov v Avstriji in Sloveniji, Poti za izboljšanje Romov v Srednji in Vzhodni Evropi. Izziv za manjšinsko pravo, INV in OOSI, Izpostava Ljubljana, Ljubljana (ur. Klopčič V. in Polzer M.)

Steklačič G., 2003. Romi v občini Grosuplje, v: Evropa. Slovenija in Romi, INV, Ljubljana, 286-302

Štrukelj P., 1979. Romi na Slovenskem, Cankarjeva založba, Ljubljana

Štrukelj P., 1991. Etnološke raziskave romske populacije v Sloveniji, Razprave in gradivo 25, INV, Ljubljana

Štrukelj P., 2004. Tisočletne podobe nemirnih nomadov, Družina, Ljubljana

Štrukelj, P., Winkler P, 1996: Romi. Enciklopedija Slovenije, 10. zvezek. Mladinska knjiga, Ljubljana.

Tancer, M., 1999. Komparativni prikaz učne uspešnosti romskih in neromskih osnovnošolcev v Prekmurju. Poti za izboljšanje Romov v Srednji in Vzhodni Evropi. Izziv za manjšinsko pravo, INV in OOSI, Izpostava Ljubljana, Ljubljana (ur. Klopčič V. in Polzer M.)

Tichy H., 1999. Izkušnje pri naporih za izboljšanje položaja Romov v Avstriji, Poti za izboljšanje Romov v Srednji in Vzhodni Evropi. Izziv za manjšinsko pravo, INV in OOSI, Izpostava Ljubljana, Ljubljana (ur. Klopčič V. in Polzer M.) 
Winkler P., 1999. Izkušnje Slovenije pri urejanju položaja Romov, Poti za izboljšanje Romov v Srednji in Vzhodni Evropi. Izziv za manjšinsko pravo, INV in OOSI, Izpostava Ljubljana, Ljubljana (ur. Klopčič V. in Polzer M.)

Zadravec J., 1991. Demografska in socialna podoba Romov v Sloveniji, Razprave in gradivo 25, INV, Ljubljana

Zupančič J., Repolusk P., Josipovič D., 2001. Problematika Romov v občini Turnišče, raziskovalna naloga, Inštitut za geografijo

Zupančič J, Kos M., et al.., 2000. Družba in prostorski razvoj Slovenije, raziskovalna naloga, Inštitut za geografijo, Ljubljana

Zupančič J., 2003. Romska vprašanja v luči prostorskih odnosov, v: Evropa, Slovenija in Romi, INV, Ljubljana, 112-129

Zupančič J., 2004. Prostorski problemi romskih naselij na Dolenjskem in v Sloveniji, Rast, št. 5 / 2004, Novo mesto, 510-523

Zupančič J., 2006. Razmere kličejo po resni strokovni presoji. Problematika romskih naselij, Delo, Sobotna priloga, 4. november 2006, str. 17-18

Zupančič J., 2006. Funkcije in problemi romskih naselij v luči boljše družbene integracije Romov, Poklicno informiranje in svetovanje za Rome-PISR, zbornik, Črnomelj, $42-56$

Zupančič J., 2006. Poti k reševanju prostorske problematike romskih naselij, Rast, 6/2006, (108), december 2006, Novo mesto, 616-627

Žagar M., 1999. Romi na Slovenskem; družbena integracija marginalnih skupnosti, Poti za izboljšanje Romov v Srednji in Vzhodni Evropi. Izziv za manjšinsko pravo, INV in OOSI, Izpostava Ljubljana, Ljubljana (ur. Klopčič V. in Polzer M.)

Žagar N., 2003. Predstavitev projekta »Romske ženske to zmoremo«, v: Evropa, Slovenija in Romi, INV, Ljubljana

Žagar N., Klopčič V., (ur.) 2006. Poklicno informiranje in svetovanje za Rome - PISR, zbornik, Črnomelj, 2006

Žnidarec Demšar S., 2006. Romi kot objekt toleriranja večine, Poklicno informiranje in svetovanje za Rome-PISR, zbornik, Črnomelj, 42-55

Žugel J., 1991. Integracija romske skupnosti v slovensko družbo, Razprave in gradivo 25, INV, Ljubljana

\section{ROMA SETTLEMENTS AS A SPECIFIC PART OF SETTLEMENT SYSTEM IN SLOVENIA}

\section{Summary}

Roma settlements represent a special spatial phenomenon in the settlement system in Slovenia. There are between 105 and 103 locations, which can be recognized as a romasettlements. The number depends of criteria, what could be treated as a roma-settlements. Trough the paper, the author anlysed 107 settlements where Roma prevails as local population. Those spatial unts are not statistical units; that s why many authors called those units diferently. Manytimes they are called by closer »other« (statistical) settlements, even thouh there exist 
specific names of this roma-settlements. Most of them are small, with less than 50 inhabitants. Only seven of them have more than 200 inhabitants and just two 500 and over. Ther are situated dispersly in panonian part of Slovenia (in the regions of Prekmurje (north-east) and Posavje, Dolenjsko, Bela krajina and Kočevsko (south-east). The rest of them live in cities (Ljubljana, Maribor, Velenje) and are immigrants of first and second generation, coming from former yugoslav republics. Just a small group, around 150 of them, are Sinti by their self-declaration, living in north-west cities (Jesenice and vicinity). They wouldn thave any connection to Roma group in Slovenia. Roma people are small endogeneous ethnic group in Slovenia, similarly like Hungarians and Italians. Statistically around 3,300 and 10,000 by estimations, live in some more than hundred spatial units - roma settlements. The paper analyse the spatial and social-geographical context of Roma settlement, in the light of contemporary social, spatial and economical changes of slovene landscapes and society.

Despite their typical small-settlement structure on the slovenian countryside, on one hand due to its natural conditions and a substantial self-will on the other hand, the Roma settlements are an exception because of their internal and external problems. Internal problems are shown in poor infrastructural equipment and - therefore - poor opportunities for achievement of basic settlement functions, as for example living, education, spending free time, work, supply and others. Those functions - except a few examples of kindergardens - cannot be offered to the inhabitants (Roma) on the place of living. The majority of Roma settlements are illegal; so many issues regarding their unsettled status and lack of systematic assistance arise. Key services depending on surrounding local centres are: supply, education, social and health care, employment and entertainment. Even the residential function of settlements is often problematic because of of prevailing negative effects of the building structure, the quality of building, piping, water and electric suply, the arrangement of residential units and - probably first of all - location of the settlements. The Roma created their settlements sporadic, dispersed and without any legistic order, on the places which has been free at that time, or take older buildings as their new homes. Thats why the Roma settlements are aesthetically ande functionally disturbing for the surrounding and local population in close social and territorial touch. This is also reflecting in the level of other relations between Roma and the local poulation in vicinity. Those contact zones are still manytimes potential (or latent) zones of confrontation and in some cases also local open conflicts.

Many Roma have serious troubles to find job; over $90 \%$ of them are unemployed constantly. Their lifestyle is between social support and provisional economic sources, as for example are ciollecting of secondary materials (paper, glas, partuicularly iron and other metals) and herb collection (now even rare). Those activities needs specific spatial conditions. There are poor opportunities for doing this in frame of roma settlements, because those the houses are too close togehter. Additionally, there is a threat of ecological harms on local or even or much larger level. All this represent a disturbing factor (stench, stain, noise, ecological threat for water sources and similar) for local inhabitants in contact zones. It will undoubtedly be necessary to pay more attention to the functioning of Roma settlements. Roma people themselves will definitely need to be engaged in the process of improving their housing conditions and at the same time offer them systematic assistance, support to persist in their participation in improving the current situation. On the other hand, marginalizing the problems 
of local population, will improve the conflictual potential and lost the labil equilibrium. The roma setllements need to change their marginal character, but not by ad hoc legalization, but with gradual structural changes, made with much bigger engagement of Roma as user and local communities (communes) as a manager of local spatial potentials and carriers of political power.

\section{PRILOGA 1}

Preglednica: Romska naselja v Sloveniji

\begin{tabular}{|c|c|c|c|c|c|c|c|c|c|}
\hline \multirow{2}{*}{ naselje } & \multirow{2}{*}{ občina } & \multirow{2}{*}{$\begin{array}{c}\text { št. } \\
\text { preb. }\end{array}$} & \multicolumn{2}{|c|}{$\begin{array}{l}\text { komunalna } \\
\text { opremljenost }\end{array}$} & \multirow{2}{*}{$\begin{array}{l}\text { delež } \\
\text { črnih } \\
\text { gradenj }\end{array}$} & \multirow{2}{*}{$\begin{array}{l}\text { lastnišstvo } \\
\text { zemljišč }\end{array}$} & \multirow{2}{*}{$\underset{\text { širitve }}{\operatorname{možnost~}}$} & \multirow{2}{*}{$\begin{array}{l}\text { možnost } \\
\text { nakupa }\end{array}$} & \multirow{2}{*}{$\begin{array}{c}\text { planska } \\
\text { urejenost, } \\
\text { status }\end{array}$} \\
\hline & & & voda & elektrika & & & & & \\
\hline Mali Šalovci & Šalovci & 26 & izvir & da & ni navedb & občina & $\mathrm{da}$ & da & urejen \\
\hline Ciganszer & Hodoš & 1 & & $\mathrm{da}$ & ni navedb & zasebno & $\mathrm{da}$ & $\mathrm{da}$ & urejen \\
\hline Dolič & Kuzma & 50 & JV & delno & večina & Romi & da & da & načrtovan \\
\hline Gornji Slaveči & Kuzma & 36 & JV & $\mathrm{da}$ & večina & Romi & da & da & načrtovan \\
\hline Donice & Kuzma & 7 & JV & $\mathrm{da}$ & delno & Romi & $\mathrm{da}$ & $\mathrm{da}$ & načrtovan \\
\hline Gornji Črnci & Cankova & 20 & lastni & $\mathrm{da}$ & delno & neznano & $\mathrm{da}$ & $\mathrm{da}$ & neznano \\
\hline Domajinci-1 & Cankova & 47 & JV & večina & delno & neznano & $\mathrm{da}$ & večina & ne \\
\hline Domajinci-2 & Cankova & 39 & izvir & $\mathrm{da}$ & delno & neznano & da & da & ne \\
\hline Gornji Črnci & Cankova & 30 & izvir & $\mathrm{da}$ & malo & neznano & $\mathrm{da}$ & da & urejen \\
\hline Hankovi & Cankova & 21 & izvir & $\mathrm{da}$ & delno & neznano & da & da & ne \\
\hline Krašči-jezero & Cankova & 23 & izvir & $\mathrm{da}$ & večina & neznano & $\mathrm{da}$ & da & ne \\
\hline Krašči-Olga & Cankova & 52 & lastni & $\mathrm{da}$ & delno & neznano & ne & da & ne \\
\hline Sotina & Rogašovci & 35 & dovoz & del & vse & Romi & $\mathrm{da}$ & $\mathrm{da}$ & urejen \\
\hline Ropoča & Rogašovci & 46 & JV & del & delno & Romi & $\mathrm{da}$ & $\mathrm{da}$ & urejen \\
\hline Pertoča & Rogašovci & 130 & JV & del & delno & Romi & $\mathrm{da}$ & $\mathrm{da}$ & urejen \\
\hline Serdica & Rogašovci & 131 & dovoz & del & večina & Romi & da & da & urejen \\
\hline Sotina-Maribor & Rogašovci & 55 & dovoz & del & delno & Romi & $\mathrm{da}$ & $\mathrm{da}$ & urejen \\
\hline Vanča vas & Tišina & 291 & lokalni & del & večina & Romi & pogojno & $\mathrm{da}$ & načrtovan \\
\hline Borejci & Tišina & 74 & lokalni & del & večina & Romi & pogojno & $\mathrm{da}$ & načrtovan \\
\hline Vadarci & Puconci & 102 & lastni & večina & delno & Romi & neznano & neznano & neznano \\
\hline Kuštanovci & Puconci & 65 & lastni & del & delno & Romi & neznano & neznano & neznano \\
\hline Dolina & Puconci & 74 & $\mathrm{JV}$ & del & večina & zasebno & odkup & neznano & neznano \\
\hline Zenkovci & Puconci & 150 & JV & večina & delno & Romi & neznano & neznano & neznano \\
\hline Dokležovje & Beltinci & 30 & JV & $\mathrm{da}$ & večina & občina & ne & neznano & urejen \\
\hline Beltinci & Beltinci & 70 & lokalni & da & večina & Romi delno & ne & neznano & urejen \\
\hline Černelavci & M. Sobota & 222 & $\mathrm{JV}$ & $\mathrm{da}$ & večina & Romi & delno & neznano & urejen \\
\hline Nemčavci & M. Sobota & 30 & JV & $\mathrm{da}$ & $\mathrm{ni}$ & Romi & $\mathrm{da}$ & $\mathrm{da}$ & urejen \\
\hline Kranjčeva u. & M.Sobota & 80 & JV & da & delno & Romi & delno & neznano & urejen \\
\hline Pušča & M.Sobota & 573 & JV & da & delno & Romi & delno & neznano & urejen \\
\hline Dolga vas & Lendava & 118 & JV & $\mathrm{da}$ & večina & SKZ & pogojno & $\mathrm{da}$ & načrtovan \\
\hline Lendava & Lendava & 48 & JV & $\mathrm{da}$ & delno & neznano & ne & ne & urejen \\
\hline Pince & Lendava & 2 & JV & $\mathrm{da}$ & neznano & neznano & ne & neznano & urejen \\
\hline Petišovci & Lendava & 9 & JV & da & neznano & neznano & neznano & neznano & urejen \\
\hline
\end{tabular}


Romska naselja kot poseben del naselbinskega sistema v Sloveniji

\begin{tabular}{|c|c|c|c|c|c|c|c|c|c|}
\hline Dobrovnik-1 & Dobrovnik & 20 & lokalni & da & delno & Romi & da & da & urejen \\
\hline Dobrovnik-2 & Dobrovnik & 30 & lokalni & da & malo & Romi & da & da & urejen \\
\hline Gomilica & Turnišče & 42 & JV & da & vse & občina & $\mathrm{da}$ & da & urejen \\
\hline Kamenci & Črenšovci & 123 & lokalni & malo & večina & $\begin{array}{l}\text { občina, } \\
\text { zasebno }\end{array}$ & da & da & urejen \\
\hline Trnje & Črenšovci & 26 & JV delno & malo & vse & $\begin{array}{c}\text { občina, } \\
\text { zasebno }\end{array}$ & pogojno & pogojno & urejen \\
\hline Brezje & $\begin{array}{l}\text { Novo } \\
\text { mesto }\end{array}$ & 268 & JV & da & delno & $\begin{array}{c}\text { občina, } \\
\text { zasebno, } \\
\text { Romi }\end{array}$ & pogojno & pogojno & urejen \\
\hline Žabjak & $\begin{array}{l}\text { Novo } \\
\text { mesto }\end{array}$ & 204 & $\mathrm{ni}$ & ni & vse & $\begin{array}{l}\text { MORS, } \\
\text { zasebno }\end{array}$ & ne & ne & ne \\
\hline Gotna vas & $\begin{array}{l}\text { Novo } \\
\text { mesto }\end{array}$ & 27 & JV & da & vse & $\begin{array}{l}\text { zasebno, } \\
\text { Romi }\end{array}$ & ne & ne & urejen \\
\hline Otočec & $\begin{array}{l}\text { Novo } \\
\text { mesto }\end{array}$ & 22 & JV & da & delno & $\begin{array}{c}\text { občina, } \\
\text { zasebno, } \\
\text { Romi }\end{array}$ & ne & ne & pogojno \\
\hline Poganci & $\begin{array}{l}\text { Novo } \\
\text { mesto }\end{array}$ & 73 & JV & da & vse & $\begin{array}{l}\text { država, šola, } \\
\text { zasebno }\end{array}$ & ne & ne & ne \\
\hline Ragovo & $\begin{array}{l}\text { Novo } \\
\text { mesto }\end{array}$ & 9 & ne & ne & vse & zasebno & ne & ne & ne \\
\hline Ruperč vrh & $\begin{array}{l}\text { Novo } \\
\text { mesto }\end{array}$ & 45 & JV & da & delno & Romi, občina & ne & ne & urejen \\
\hline Šmihel & $\begin{array}{l}\text { Novo } \\
\text { mesto }\end{array}$ & 112 & JV & da & večina & $\begin{array}{l}\text { občina, Romi, } \\
\text { zasebno }\end{array}$ & ne & ne & urejen \\
\hline Roje & Šentjernej & 8 & JV & $\mathrm{da}$ & vse & SKZ & ne & ne & urejen \\
\hline Draškovec & Šentjernej & 25 & JV & da & vse & $\begin{array}{c}\text { država, } \\
\text { zasebno }\end{array}$ & ne & ne & ne \\
\hline Kozarje & Šentjernej & 18 & JV & da & večina & Romi & ne & ne & urejen \\
\hline Mihovica & Šentjernej & 30 & JV & da & vse & SKZ, Romi & ne & ne & urejen \\
\hline Trdinova cesta & Šentjernej & 77 & JV & $\mathrm{da}$ & vse & SKZ, občina & delno & ne & urejen \\
\hline Dobruška vas-1 & Škocjan & 50 & ne & ne & vse & zasebno & ne & ne & ne \\
\hline Dobruška vas-2 & Škocjan & 120 & ne & ne & vse & zasebno & ne & ne & ne \\
\hline Čudno selo & Čnomelj & 27 & ne & da & vse & Romi & da & ne & urejen \\
\hline Drenovec & Črnomelj & 38 & delno & da & malo & Romi, občina & da & da & urejen \\
\hline Lokve & Črnomelj & 286 & JV & delno & vse & $\begin{array}{c}\text { Romi, } \\
\text { zasebno, } \\
\text { občina, SKZ }\end{array}$ & da & delno & urejen \\
\hline Kanižarica & Črnomelj & 153 & ne & $\mathrm{da}$ & večina & $\begin{array}{c}\text { Romi, občina, } \\
\text { zasebno }\end{array}$ & delno & delno & urejen \\
\hline Blatnik & Semič & 15 & JV & da & večina & $\begin{array}{c}\text { Romi, } \\
\text { zasebno }\end{array}$ & delno & da & delno \\
\hline Semič & Semič & 9 & ne & da & delno & zasebno & ne & ne & urejen \\
\hline Belečnik & Semič & 29 & dovoz & ne & vse & $\begin{array}{c}\text { zasebno, } \\
\text { Romi }\end{array}$ & ne & ne & ne \\
\hline Sovinek & Semič & 44 & dovoz & $\mathrm{da}$ & delno & občina & da & da & urejen \\
\hline Srednja vas & Semič & 43 & JV & delno & malo & Romi & $\mathrm{da}$ & $\mathrm{da}$ & urejen \\
\hline Svržaki & Metlika & 41 & JV & delno & večina & občina & da & $\mathrm{da}$ & načrtovan \\
\hline Boriha & Metlika & 114 & JV & da & vsi & $\begin{array}{l}\text { občina, } \\
\text { zasebno }\end{array}$ & da & $\mathrm{da}$ & načrtovan \\
\hline Gaugen hrib & Metlika & 49 & JV & delno & delno & Romi & $\mathrm{da}$ & da & načrtovan \\
\hline $\begin{array}{l}\text { Doljne } \\
\text { Dobravice }\end{array}$ & Metlika & 43 & JV & da & vse & $\begin{array}{l}\text { občina, } \\
\text { zasebno, } \\
\text { Romi }\end{array}$ & $\mathrm{da}$ & $\mathrm{da}$ & urejen \\
\hline Gradac & Metlika & 36 & JV & da & vse & $\begin{array}{l}\text { občina, } \\
\text { zasebno }\end{array}$ & da & $\mathrm{da}$ & urejen \\
\hline Krušče & Brežice & 60 & pipa & ne & vse & zasebno & ne & da & ne \\
\hline Drnovo & Krško & 38 & lastni & da & vse & $\begin{array}{c}\text { zasebno, } \\
\text { Romi }\end{array}$ & ne & $\mathrm{da}$ & urejen \\
\hline Kerinov grm & Krško & 170 & JV & ne & vse & občina & da & da & urejen \\
\hline Leskovec & Krško & 52 & lokalni & ne & vse & zasebno & da & $\mathrm{da}$ & urejen \\
\hline Rimš & Krško & 44 & dovoz & ne & vse & škofija & ne & ne & ne \\
\hline Hudeje & Trebnje & 250 & JV & malo & vse & $\begin{array}{c}\text { občina } \\
\text { zasebno }\end{array}$ & da & pogojno & urejen \\
\hline
\end{tabular}




\begin{tabular}{|c|c|c|c|c|c|c|c|c|c|}
\hline Korita & Trebnje & 9 & lastni & delno & vse & zasebno, SKZ & da & da & urejen \\
\hline Mala Loka & Trebnje & 7 & lastni & ne & vse & SKZ & da & da & urejen \\
\hline Trebnje & Trebnje & 5 & JV & $\mathrm{da}$ & $\mathrm{ni}$ & zasebno & ne & ne & urejen \\
\hline Gline & Trebnje & 12 & JV & ne & vse & zasebno & $\mathrm{da}$ & $\mathrm{da}$ & urejen \\
\hline Zagorica & Trebnje & 13 & JV & ne & vse & zasebno & $\mathrm{da}$ & pogojno & urejen \\
\hline Šranga & Mirna peč & 6 & JV & da & $\mathrm{ni}$ & Romi & da & ni potreb & urejen \\
\hline Vrhpolje & $\begin{array}{l}\text { Ivančna } \\
\text { gorica }\end{array}$ & 7 & ne & ne & vse & zasebno & delno & ni potreb & možno \\
\hline Smrekec 1 & Grosuplje & 53 & JV & ne & vse & $\begin{array}{l}\text { občina, } \\
\text { zasebno }\end{array}$ & ne & ne & ne \\
\hline Smrekec 2 & Grosuplje & 57 & $\mathrm{JV}$ & ne & vse & $\begin{array}{l}\text { občina, } \\
\text { zasebno }\end{array}$ & ne & ne & ne \\
\hline Oaza & Grosuplje & 31 & JV & ne & vse & $\begin{array}{c}\text { zasebno, } \\
\text { občina }\end{array}$ & ne & ne & ne \\
\hline Niko & Grosuplje & 29 & JV & ne & vse & SKZ, zasebno & ne & ne & ne \\
\hline Benat & Grosuplje & 20 & potok & ne & vse & Romi & ne & ne & ne \\
\hline Trata-jezero & Kočevje & 21 & pipa & $\mathrm{da}$ & vse & $\begin{array}{l}\text { občina, } \\
\text { zasebno }\end{array}$ & ne & ne & ne \\
\hline Marof & Kočevje & 27 & JV & da & delno & SKZ, občina & ne & ne & ne \\
\hline Kočevje & Kočevje & 33 & ne & ne & vse & SKZ, občina & ne & ne & ne \\
\hline Željne & Kočevje & 186 & ne & ne & večina & SKZ, občina & ne & ne & urejen \\
\hline Griček & Kočevje & 19 & JV & $\mathrm{da}$ & vse & občina & ne & ne & ne \\
\hline Trata-betonarna & Kočevje & 65 & ne & ne & vse & občina & ne & ne & ne \\
\hline Goriča vas & Ribnica & 69 & ne & ne & vse & $\begin{array}{c}\text { zasebno } \\
\text { MORS } \\
\text { Romi } \\
\end{array}$ & ne & ne & ne \\
\hline Lepovče & Ribnica & 52 & ne & ne & vse & občina & ne & ne & ne \\
\hline Otavice & Ribnica & 8 & ne & ne & vse & zasebno & ne & ne & ne \\
\hline \multicolumn{10}{|l|}{ SINTI } \\
\hline Podkočna & Jesenice & 6 & $\mathrm{JV}$ & $\mathrm{da}$ & $\mathrm{ni}$ & občina & neznano & neznano & neznano \\
\hline Na Potokih & Jesenice & družina & JV & $\mathrm{da}$ & $\mathrm{ni}$ & lastno & neznano & neznano & neznano \\
\hline Žirovnica & Žirovnica & 22 & $\mathrm{JV}$ & $\mathrm{da}$ & $\mathrm{ni}$ & SKZ & neznano & neznano & neznano \\
\hline Kranj & Kranj & družina & JV & da & $\mathrm{ni}$ & lastno & neznano & neznano & neznano \\
\hline Rečica & Bled & družina & JV & $\mathrm{da}$ & $\mathrm{ni}$ & lastno & neznano & neznano & neznano \\
\hline Kamna gorica & Kropa & družina & JV & $\mathrm{da}$ & $\mathrm{ni}$ & lastno & neznano & neznano & neznano \\
\hline Radovljica & Radovljica & družina & JV & $\mathrm{da}$ & $\mathrm{ni}$ & lastno & neznano & neznano & neznano \\
\hline \multicolumn{10}{|l|}{$\begin{array}{l}\text { PRISELJENI } \\
\text { ROMI }\end{array}$} \\
\hline Litijska c & Ljubljana & 52 & JV & $\mathrm{da}$ & vse & neznano & neznano & neznano & neznano \\
\hline Ljubljana ostalo & Ljubljana & 600 & delno & delno & večina & različno & delno & delno & urejen \\
\hline Maribor & Maribor & 1300 & delno & delno & večina & različno & delno & delno & urejen \\
\hline Velenje & Velenje & 150 & JV & $\mathrm{da}$ & $\mathrm{ni}$ & zasebno & da & da & urejen \\
\hline
\end{tabular}

Viri:

-Anketa: Romska naselja v Sloveniji, Strokovna skupina za reševanje prostorske problematike romskih naselij v Sloveniji, MOP, februar-marec 2007, vse upravne enote RS, za vsako romsko naselbino posebej -Bivalne razmere Romov po občinah v Sloveniji, Urad RS za narodnosti, 2004-2005, interno gradivo -Štrukelj P., 2004, Tisočletne podobe nemirnih nomadov, Družina, Ljubljana, 309

Opombe:

-zaradi pomanjkanja prostora je pregled posplošen

-kratice (JV-javni vodovod; SKZ- sklad kmetijskih zemljǐ̌č) 